\title{
What does Voluntary Delisting Tell us about Corporate Governance in Kuwait?
}

\author{
Shahad M. Almutairi \\ University of Leeds, Belle Vue Road, Woodhouse, Leeds LS2 9JT, UK \\ Mli4smss@leeds.ac.uk
}

\begin{abstract}
Despite the adoption of the mixed approach in the application of corporate governance (CG), largely based on the 'comply or explain' principle, the Kuwaiti corporate governance system still faces major limitations that have become particularly noticeable from the event of voluntary delisting by a slew of companies after the new Kuwaiti Code of Corporate Governance (KCCG) came into force in 2016. One apparent limitation is caused by the widespread culture of non-compliance, an observation supported by the Capital Market Authority Report on Voluntary Delisting from 2010 to 2016. Empirical analysis was conducted on a sample of 29 companies, all of which were delisted during application of the new KCCG of 2015 until April 2020. This voluntary delisting also indicates other salient limitations such as deficiencies in the CG legal framework, the asymmetrical concentration of share ownership in the hands of larger shareholders, and the passivity of shareholders in Kuwaiti-listed shareholding companies.
\end{abstract}

\section{Keywords}

corporate governance - Kuwait - voluntary delisting - concentrated ownership shareholder activism

The corporate governance framework in Kuwait has evolved significantly over the past decade. It requires an extensive examination to cover the dearth of studies about the effectiveness of this framework. The legal framework 
of corporate governance (CG) in Kuwait, similarly to most systems, consists of laws, regulations, and codes. ${ }^{1}$ The Kuwaiti Companies Law 2016 (KCL) sets out the basic governance structure that is mandatory for all companies incorporated in Kuwait. ${ }^{2}$ Meanwhile the Corporate Governance Code of 2015 (KCCG 2015), which is Module 15 of the Capital Market Authority's (CMA) Executive Bylaws, has a limited scope, applying only to companies listed on the Boursa or CMA-licensed companies. ${ }^{3}$ Two CG codes have been issued in Kuwait: the first code (KCCG 2013) was a binding approach, while the second code (KCCG 2015) was a mixed approach mainly based on the 'comply or explain' concept, which is a trademark of corporate governance in the UK. ${ }^{4}$ The borrowed concept is far from perfect as it does not live up to its aims, mainly failing to deliver flexibility. This article addresses the question of what the limitations of corporate governance are that hinder the good corporate governance practice in the Kuwaiti system. This article answers this question by looking at voluntary delisting using doctrinal research and empirical analysing of the newly updated data available on official websites. Studying the Kuwaiti legal framework of corporate governance allows for construction of a picture of its weaknesses in solving the CG limitations. Thus, this article has suggested a number of recommendations to enhance the efficiency of the Kuwaiti legal system and follow other countries' approach for more harmonisation of codes and regulations between countries in the region.

We aim to contribute to knowledge in five ways: (1) by examining the event of voluntary delisting from a perspective of corporate governance, (2) by empirically supporting the existence of a non-compliance culture of listed companies, and defining it in the Kuwaiti context, (3) by presenting a critical analysis of the challenges of the CG legal framework, (4) by providing reasons behind the absence of shareholder activism in Kuwait, and (5) by providing the normative claim and justification for regulatory reforms to create efficiency and harmonise the code and regulations between the Middle East and North African (MENA) country members. This research is divided into four sections. Following this Introduction, Section 2 examines the phenomena of

1 Alissa Amico, 'Corporate Governance Enforcement in the Middle East and North Africa', OECD Corporate Governance Working Papers No. 15 (2014), p. 17, available online at https:// www.oecd-ilibrary.org/docserver/5jxws6scxg7c-en.pdf?expires=16186o1511\&id=id\&accname =guest\&checksum=545E7DBBo47DB1094C9819752554CFEB (accessed 16 April 2021).

2 Kuwaiti Companies Law No. 1, 2016, Article 1.

3 Kuwait, CMA, Executive Bylaws, Module 15: Corporate Governance 2015, Article 1-3.

4 Financial Reporting Council (FRC), UK Corporate Governance Code (September 2012), available online at https://www.frc.org.uk/getattachment/e322c2oa-1181-4ac8-a3d3-1fcfbcea7914 /UK-Corporate-Governance-Code-(September-2012).pdf (accessed 16 January 2021), p. 4. 
voluntary delisting in the past as well as the present in the Kuwait Boursa and presents the results of the Capital Market Authority Report for 2010-2016 when companies reported voluntary delistings. The CMA concluded that voluntary delisting was the result of the high cost of CG requirements and the stringent provision of mandatory acquisition. At the same time, the CMA recognised the prevailing behaviour of companies in preferring to avoid any legal responsibility as a reason for delisting. The section then provides an overview of the compliance approach of the new KCCG 2015 and raises the question of the efficiency of the new code due to the increasing number of voluntary delistings. Section 3 provides a critical examination of important limitations that hinder good CG practice in the Kuwaiti system. This examination is driven by the question: What are the main limitations of corporate governance in Kuwait? As shown in Figure 1, there are four key limitations of corporate governance in Kuwait, which are: (1) the culture of non-compliance; (2) deficiencies in the legal framework of corporate governance, which includes (a) deficiencies in the CG approach (including the application of the code in a way that does not take into account the size of a company, inadequate evaluative statistics and data on the approach, and, most importantly, a refusal to recognise the noncompliance culture of companies); (b) fragility in the Kuwait Companies Law

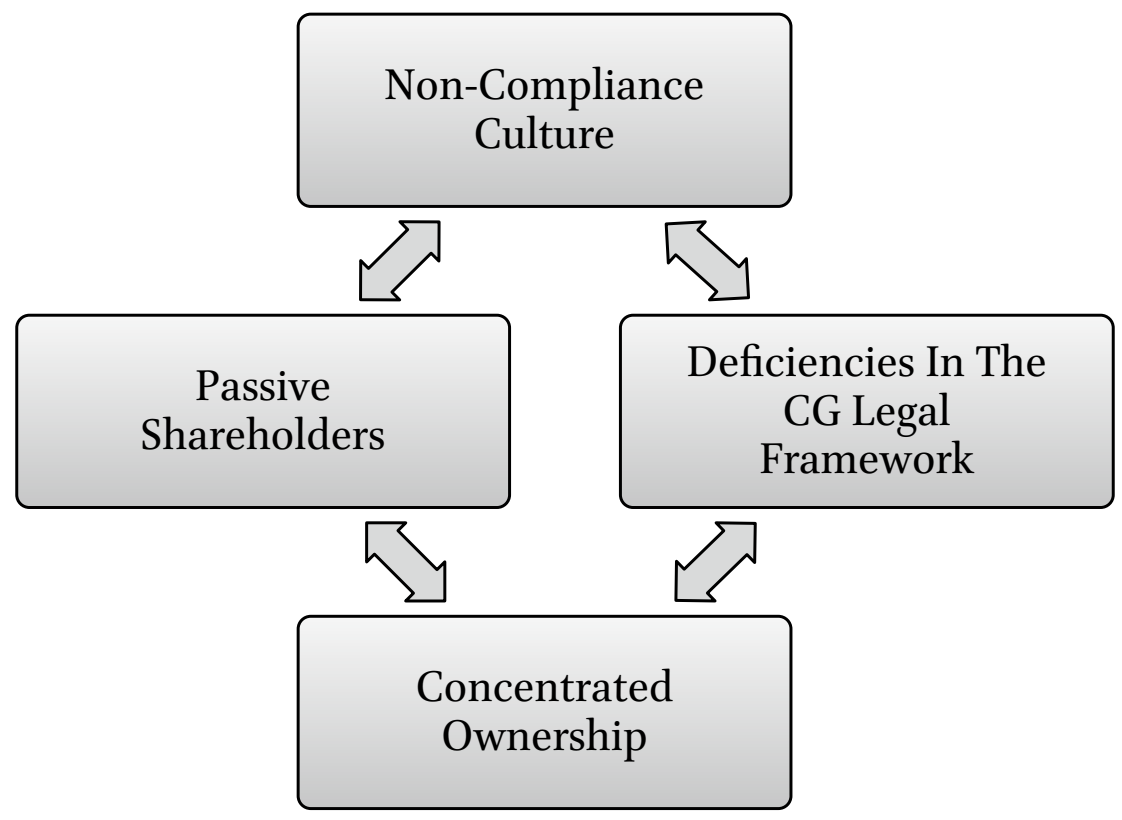

FIGURE 1 The cycle of corporate governance limitations 
2016 (KCL 2016); (3) concentration of ownership, which has encouraged large shareholders to exploit the law, in a way that can negatively affect minority rights. Also, it creates an agency problem between the groups of major shareholders, who become 'insiders' due to their substantial representation on boards, and minority shareholders (although each of these groups has a negative impact on good CG practice); and (4) the passive shareholders in Kuwaiti companies, which can contribute to two sets of issues: (a) legal issues and (b) cultural and social issues. Following this discussion, Section 4 concludes by addressing the connections between the limitations and recommends reforms for the regulator to resolve the limitations of corporate governance in Kuwait.

\section{2 \\ Voluntarily Delisting in the Past and Present}

The cma Executive Bylaws provide an option and procedure for a listed shareholding company to request to delist voluntarily from the Exchange. ${ }^{6}$ However, voluntary delisting from the Exchange has become an option that has attracted the attention of politicians, investors, and security regulators. ${ }^{7}$ In 2014 , the Kuwait Parliament questioned the former Minister of Trade and Industry about voluntary delisting, referring to it as a phenomenon that threatens the Emirate's reputation. ${ }^{8}$ In response, the 'Market Regulation Department' and the 'Capital Market Research and Development' section of the CMA investigated the reasons behind the increasing number of voluntary withdrawals. ${ }^{9}$ It is important to examine voluntary withdrawals because the option indicates a

5 This is an important limitation as the KCL 2016 is the basis for the CG legal framework. The key deficiency in the KCL is the OTC, a market with no CG requirements or supervision by the CMA. Companies take advantage of the отс being outside the reach of any legal restraints. Because of its weaknesses, the KCL 2016 does not constitute a sufficient source of corporate governance and does not give the ministry sufficient supervision over companies. Also, the fragility of the provisions aligns with the responsibilities of boards of directors, which enable the major shareholders to dominate.

6 Kuwait, CMA, Executive Bylaws, Module 12: Listing Rules (2015), Article 1-6.

7 See https://www.cma.gov.kw/en/web/cma/cma-board-releases/-/cmaboardreleases/detail / 455754 (accessed 16 April 2021).

8 The parliamentary question from Abdullah Mohammed al-Turiji was directed at the Vice Prime Minister and the Minister of Trade and Industry, Abdul Mohsen al-Madaj, 'Inquiries about companies' withdrawal from the Capital Markets Authority since the Authority assumed its duties, and about the current Chairman of the Authority reaching the legal retirement age' (Term of Assembly No. 14, Annual Session No. 3, Record 1163), available online at http://search.kna.kw/web/Retrieval/DocumentsView.aspx?DocIDs $=\left\{04 \mathrm{E} 27 \mathrm{C}_{51}-\mathrm{D} 8 \mathrm{E} 6-44 \mathrm{~F} 4\right.$ -BC65-FD821988E362\},\&dc=1 accessed 16 April 2021).

9 Available online at https://www.cma.gov.kw/en/web/cma/cma-board-releases/-/cmaboard releases/detail/455754 (accessed 16 April 2021). 
deficiency in the CG system. The CMA study notes that one common reason for companies withdrawing from the list was the strict CG requirements of KCCG 2013, as is explored below. However, the continuous withdrawal of companies indicates some flow in the CG system. Therefore, this section examines the phenomenon of voluntary withdrawal from the Kuwait Boursa during application of the old KCCG 2013 and the new KCCG 2015.

\subsection{Voluntarily Delisting during Application of the KCCG 2013}

In December 2016, the CMA held an Awareness Workshop about the voluntary event in the Kuwait Boursa to share the results of its Report; ${ }^{10}$ the Authority emphasised the important role of the CMA in raising awareness and encouraging companies and investors to be listed on the Kuwaiti Boursa. ${ }^{11}$ The CMA Report studied 42 companies that had delisted from the market since the establishment of the CMA in 2010 until December $2016 .{ }^{12}$ It found that 17 companies had voluntarily withdrawn from the stock exchange after the approval of at least $51 \%$ of their general assemblies. ${ }^{13}$ The cMA presented the reasons provided by the boards of directors of the companies that withdrew, which led to voluntary exiting from the market. ${ }^{14}$ These reasons concerned the declining classification of the Kuwaiti Boursa, the high cost of listing fees, the stringent provision of mandatory acquisition, and, most importantly, the high cost of application of the CG code. ${ }^{15}$

However, the CMA only placed merit on the last two reasons. ${ }^{16}$ First, the CMA's insistence on enforcing the mandatory takeover provisions represented

10 There is a shortage of written data from the CMA because they did not publish the results of the report concerning the voluntarily withdrawal. However, the official CMA website provides the general results in a PowerPoint presentation in the scientific material and in a video available on the official channel of the CMA; these are the only available resources showing CMA's complete opinion about the problem of voluntarily withdrawal. Thus, this research makes use of these online materials.

11 CMA_KWT, 'Workshop: Voluntary Withdrawals for Listed Companies 6/12/2016' (24 Dec. 2018), available online at https://www.youtube.com/watch?time_continue $=278$ $\& \mathrm{v}=$ CLkisoLdbzM\&feature=emb_logo (accessed 16 April 2021); henceforth referred to as Video_Workshop.

12 Capital Markets Authority-Market Sector, 'An Awareness Workshop: Voluntary Withdrawals of Listed Companies from the Kuwait Stock Exchange' (CMA, 2016) under the name of scientific material, available online at https://www.cma.gov.kw/en/web/cma /awarenessevents/-/cmageneric/455868 (accessed 16 April 2021); slide 9 henceforth referred to as the PowerPoint_Workshop.

13 PowerPoint_Workshop, slide 9 .

14 Ibid., slide 15.

15 Ibid.

16 Ibid., slide 20. 
a reasonable ground for most companies' withdrawal from the Boursa. ${ }^{17}$ Under the mandatory takeover provisions, a shareholder who acquires more than $30 \%$ of a listed company's shares is required to submit an offer to purchase all the remaining shares..$^{18}$ Some investors who own $30 \%$ or more of a company do not have the desire or the financial ability to buy the company, but, at the same time, cannot scale down their stake. ${ }^{19}$ The CMA Report suggested that the decision to voluntarily delist was made by an alliance of investors subject to mandatory takeover provisions and 'dominant groups' of shareholders to avoid the obligations under the mandatory takeover provisions. ${ }^{20}$ The CMA considered the problems surrounding the mandatory takeover provisions when issuing the new regulations of Law No. 7 of $2010 .{ }^{21}$ In particular, the Authority considered and applied international best practice in regulating the Executive Bylaws-Module 9, Mergers and Acquisitions (Articles 3-5-1 and 3-6). ${ }^{22}$ Accordingly, since the new regulations have been introduced, the CMA has managed 15 cases that have been exempted from the mandatory takeover provisions, where it has decided to reschedule the percentage of the sale and purchase of the controlling shares of the listed companies, consistent with Kuwaiti market conditions. ${ }^{23}$ Thus, the CMA believes that the mandatory takeover provisions are no longer a legitimate reason for companies to exit the Boursa. ${ }^{24}$

Second, and perhaps more significantly, the CMA found that the most frequently cited reason for withdrawal in the requests to delist voluntarily concerned the application of corporate governance. ${ }^{25}$ The cMA Report estimated that the financial cost the companies bore to meet the requirements ranged from 150 ooo to 300 ooo Kuwaiti dinars (KD), depending on the size of the company. ${ }^{26}$ The cost is considered rather high, especially for companies making small profits. ${ }^{27}$ However, the CMA believed that the problem had been solved under the new KCCG 2015, which adopted a piecemeal approach to corporate governance rules based on the 'comply or explain' approach. ${ }^{28}$ Thus,

\footnotetext{
17 Video_Workshop, supra note 11 at 30:0o.

18 Kuwait, CMA Executive Bylaws, Module 9: Mergers and Acquisitions 2015, Article 3-5-1.

19 Video_Workshop, supra note 11 at 30:37-30:53.

$20 \quad$ Ibid., 30:58 to 31:o9.

21 PowerPoint_Workshop, supra note 12 at slide 20.

22 Ibid., slide 21.

23 Ibid.

24 Video_Workshop, supra note 11 at 31:26-31:30.

25 Ibid., 30:19-30:28.

$26 \quad$ Ibid., 31:38-31:53.

27 Ibid., 31:54-32:06.

28 PowerPoint_Workshop, supra note 12 at slide 21.
} 
the CMA Report removed the strict application of the CG code as a reason for companies to continue alienating from the market. ${ }^{29}$

Finally, the CMA Report discussed how the phenomenon of voluntary delisting reflected the mind-set and the stereotype of most companies in Kuwait. If a company makes stable profits, has no plans to extend its business, and, most importantly, has its share of ownership concentrated in the hands of the dominant groups, then the company's shares would not be tradable. ${ }^{30}$ Since their shares are not tradable, the company prefers to distance itself from the exchange so that it is protected from the supervising authority and any legal obligations. ${ }^{31}$ These three factors create a mind-set similar to the 'family' company in Kuwait, that sees no benefit in being listed on the exchange, ${ }^{32}$ especially considering that $35 \%$ of voluntarily delisted companies in the CMA Report that were meeting the listing requirements of the Boursa still chose to delist. ${ }^{33}$

To sum up, the first CG code (KCCG 2013) did not provide a successful approach to corporate governance. The strict approach to the application of corporate governance discouraged companies from listing on the market, rather than encouraging them to voluntarily delist to avoid the expensive requirements of the CG code. However, the most important question raised is: Will changing the approach to a more recognisable and flexible approach be sufficient, especially when there is already a prevailing non-compliance culture among companies in Kuwait?

\subsection{Voluntarily Delisting during Application of the KCCG 2015}

As suggested earlier, companies faced challenges in applying such a hard code' approach to corporate governance: the research content that the voluntary delisting was one of the challenges of the old approach. These challenges drove the move to recalibrate the application of corporate governance from a hard approach to a more flexible one. The CMA issued a new CG code (KCCG 2015), which adopted a hybrid approach, comprising both compulsory and optional rules. ${ }^{34}$ The enforcement approach of the optional rules is generally

29 Video_Workshop, supra note 11 at 32:40-32:47.

3 o Ibid., 38:oo-38:19.

$31 \quad$ Ibid., 38:20-38:28.

$32 \quad$ Ibid., 38:29-38:38.

33 PowerPoint_Workshop, supra note 12 at slide 14.

34 Abdullah Alshebli, 'Towards Overcoming the Challenges of Applying Corporate Governance: The Effectiveness of the Principle of Comply or Explain as a Mechanism for Implementation: A Comparative Study', Kuwait Univesity Journal of Law 123(43) (2019): 125 . 
based on the 'comply or explain' principle. ${ }^{35}$ According to this approach, companies subject to corporate governance have two options: to fulfil the requirements of this code and reveal the degree of their compliance in CG reports or disclose every rule not complied with and justify in great detail the reasons behind their non-compliance. ${ }^{36}$

However, enforcement of the compulsory rules stands within the 'commitment and compliance' approach to which these rules pertain as follows:

a. board member independence;

b. integrity of financial reporting;

c. robust risk management and internal audit systems;

d. ensuring timely and high-quality disclosure and transparency; and

e. respecting shareholders' rights. ${ }^{37}$

The latter approach means that companies are subject to penalties in cases of non-compliance. ${ }^{38}$ Under the new KCCG 2015, the application of corporate governance is mainly based on the 'comply or explain' principle, with certain narrow exceptions, which apply a binding approach. Thus, the new Kuwaiti code is not fully voluntary, but rather contains voluntary and compulsory rules, namely a mix of soft and hard law.

Surprisingly, in 2017, 20 companies delisted from the Boursa. ${ }^{39}$ As shown in Figure 2, this was a dramatic increase in the number of delisted companies in comparison to the previous and subsequent years. What is also surprising is that 18 of the 20 companies voluntarily delisted from the market. ${ }^{40}$ To understand how large this number is, consider that 17 companies delisted between 2010 and 2016, a 7-year period. It is crucial to emphasise that 2017 was the year after the mixed-approach KCCG 2015 came into force. The fact that companies continued to exit from the market even after adoption of a more

35 Most of the GCC countries have adopted the 'comply or explain' approach in their codes; however, the UAE did not as their code approach is based on mandatory compliance ('comply or pay penalty').

36 Kuwait, CMA, Executive Bylaws, Module 15: Corporate Governance (2015), Article 1-1.

37 Ibid.

38 Ibid., Article 1-2.

39 Available online at https://www.boursakuwait.com.kw/en/securities/company-informa tion/delisted-companies (accessed 16 April 2021).

40 CMA, 6th Annual Report (2016-2017), p. 52; CMA, 7th Annual Report (2017-2018), p. 88; FXNEWSTODAY, 'Withdrawal of (Flex) from the Market from Jan 31, 2017', available

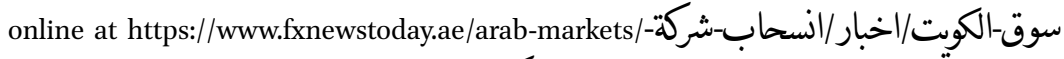
170790-2017-10-31-منكس)-من-السوق-اعتبار ا-من/Waccessed 16 April 2021); FXNEWSTODAY, 'The Withdrawal of the Company (MARIN) from the Market on o6/o7/2017', available

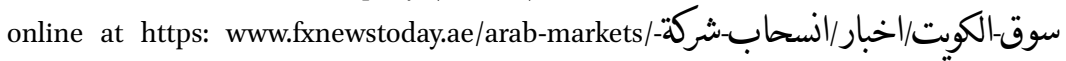
-بكرية-(من-السوق-اعتبارا-من-06-06-(accessed 16 April 2021). 


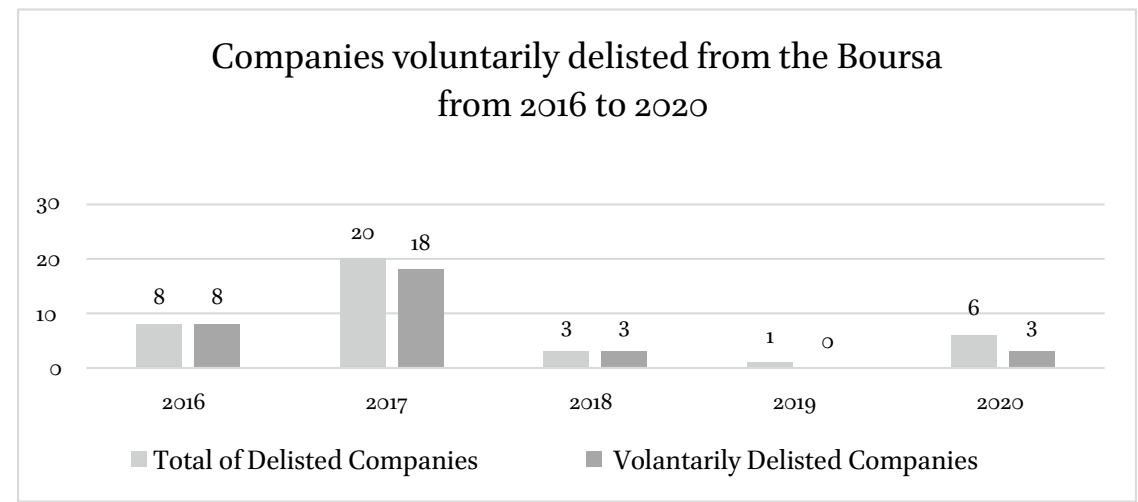

FIGURE 2 The number of voluntarily delisted companies among the total number of delisted companies from 2016 to 2020 SOURCE: HTTPS://WWW.BOURSAKUWAIT.COM.KW/EN/SECURITIES/ COMPANY-INFORMATION/DELISTED-COMPANIES (ACCESSED 16 APRIL 2021)

flexible approach may indicate deficiencies in the CG system. Thus, we must ask: What are the limitations of corporate governance in Kuwait support the continues of the event of voluntarily delisting?

\section{$3 \quad$ Key Limitations of Corporate Governance System in Kuwait}

\subsection{Culture of Non-Compliance}

The CMA's recognition of the culture of non-compliance among the delisted companies from 2010 to 2016 was conform the findings of the OECD study that several companies were delisted from the Kuwait Boursa for failing to meet disclosure requirements. ${ }^{41}$ This article claims that the culture of non-compliance still exists among delisted companies despite adoption of the more flexible approach of KCCG 2015. Thus, this section is aimed at empirically examining the existence of this culture within the application of this new CG code.

\subsubsection{The Sample and Questions}

A sample of delisted companies was collected in order to link the problem of voluntary withdrawal with the culture of non-compliance. This sample consists of 29 companies, all of which delisted from 30 June 2016, the date when the KCCG 2015 came into force, to April 2020. In this sample, 26 companies

41 OECD, The Role of MENA Stock Exchanges in Corporate Governance Report (2012), p. 42, available online at https://www.oecd.org/daf/ca/RoleofMENAstockexchanges.pdf (accessed 16 April 2021). 
voluntarily withdrew from the market. In addition, two companies in the sample were compulsorily delisted by the CMA. In addition, one company delisted from the Boursa due to liquidation. The capital of the delisted companies, operating in different sectors, ranged from less than 10 million KD to 200 million KD. The sample was collected from the Boursa's official website, from a total of $5^{2}$ delisted companies added on the website between 2012 and April 2020. Thus, the sample represents $55.7 \%$ of the total number of delisted companies. Important questions related to this sample are:

1. How many companies voluntarily delisted from the Boursa?

2. How many companies did not submit a first CG report in 2016?

3. How many companies did not attend the Corporate Governance Awareness Workshop organised by the CMA?

4. How many companies were sanctioned by the CMA?

5. How many companies are no longer within the scope of applying the KCCG 2015? Are the companies still licensed?

6. How many voluntarily delisted companies are registered on the over-thecounter (отC) market?

3.1.2 The Analysis

As shown in Table 1, 26 out of 29 companies voluntarily exited from the market; this represents $89.6 \%$ of the total number of delisted companies in the sample. This research divides the non-compliance culture in Kuwaiti context into two aspects: the lack of discipline and education, and alienation from the scope of corporate governance. The available evidence concerning the first aspect is the list of companies that did not submit an CG Annual Report, the record of the CMA concerning the sanctions imposed on companies and the list of companies that did not attend the CG Awareness Workshop. Meanwhile, the second aspect is supported by examining the lists of CMA-licensed companies and the list of companies registered on the отс.

1. Examination of the first aspect: lack of discipline and education

a. Companies within the CG scope are required to submit a CG Report in the Annual Report to the CMA. ${ }^{42}$ Only one list of companies that did not submit the report is available, during the first year of the new KCCG $2015 .{ }^{43}$ The companies had to submit within 10 days after

42 Kuwait, CMA, Executive Bylaws, Module 15 Corporate Governance (2015), Article 3-7.

43 It could be argued that this was the first list and thus does not reflect the level of companies' understanding of corporate governance requirements. However, companies have experienced a more restricted corporate governance system in 2013 until 2014. The CMA postponed the date of complying with the new Corporate Governance Code from 31 December 2014 to 30 June 2016 to give companies time to prepare. Companies were also invited to the CMA Awareness Workshop, which was held for 2 weeks. Moreover, the 


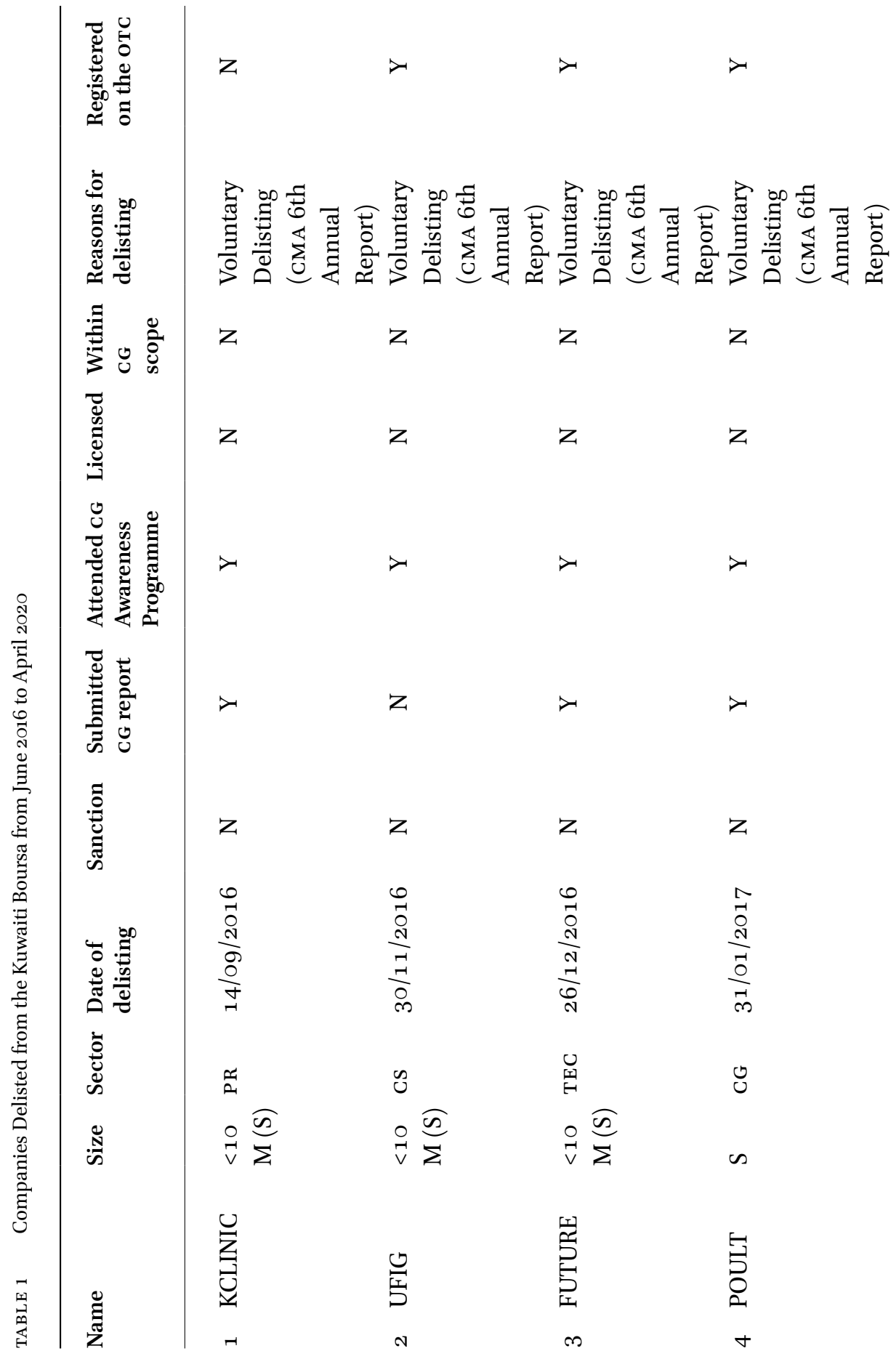




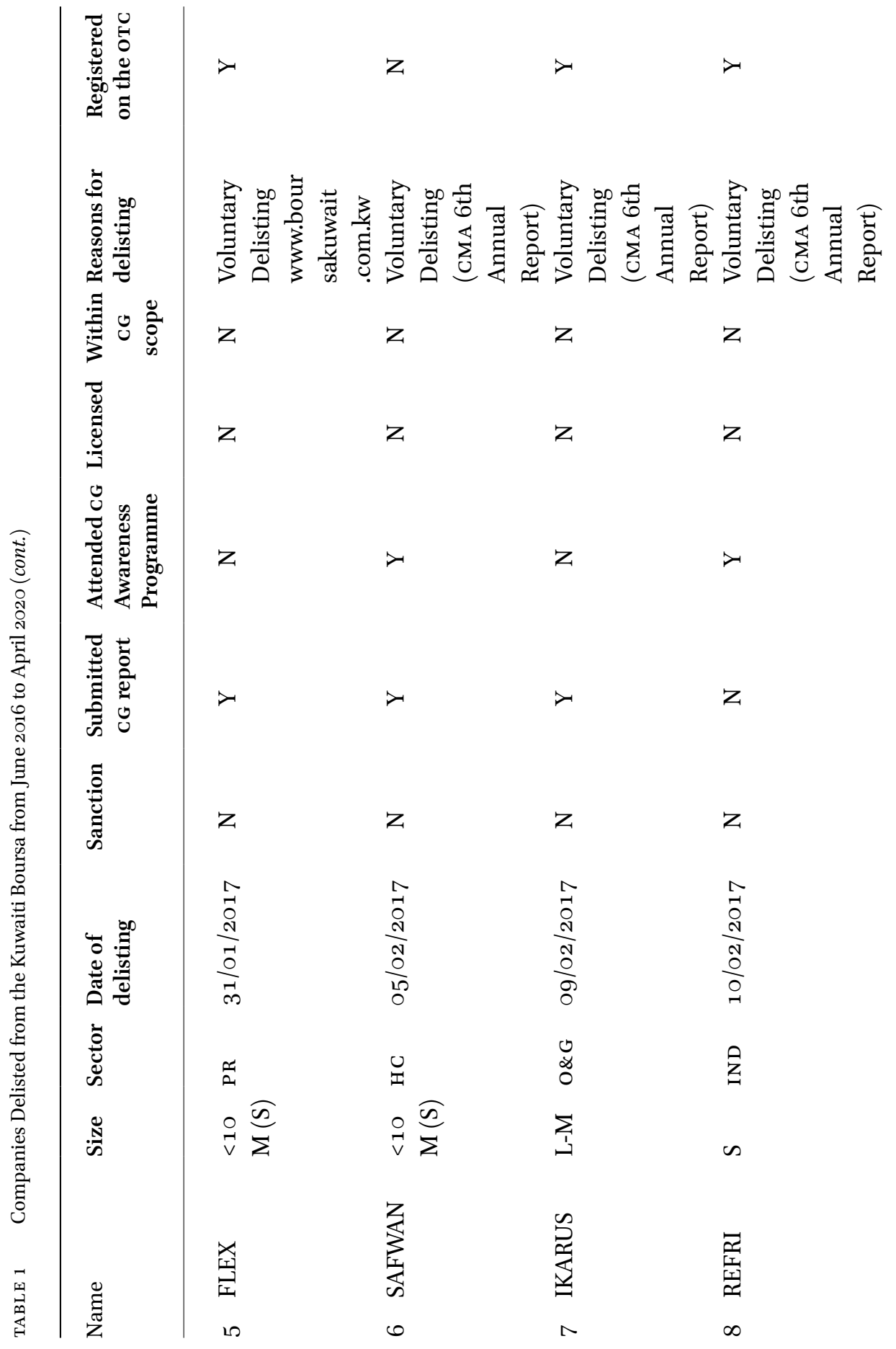




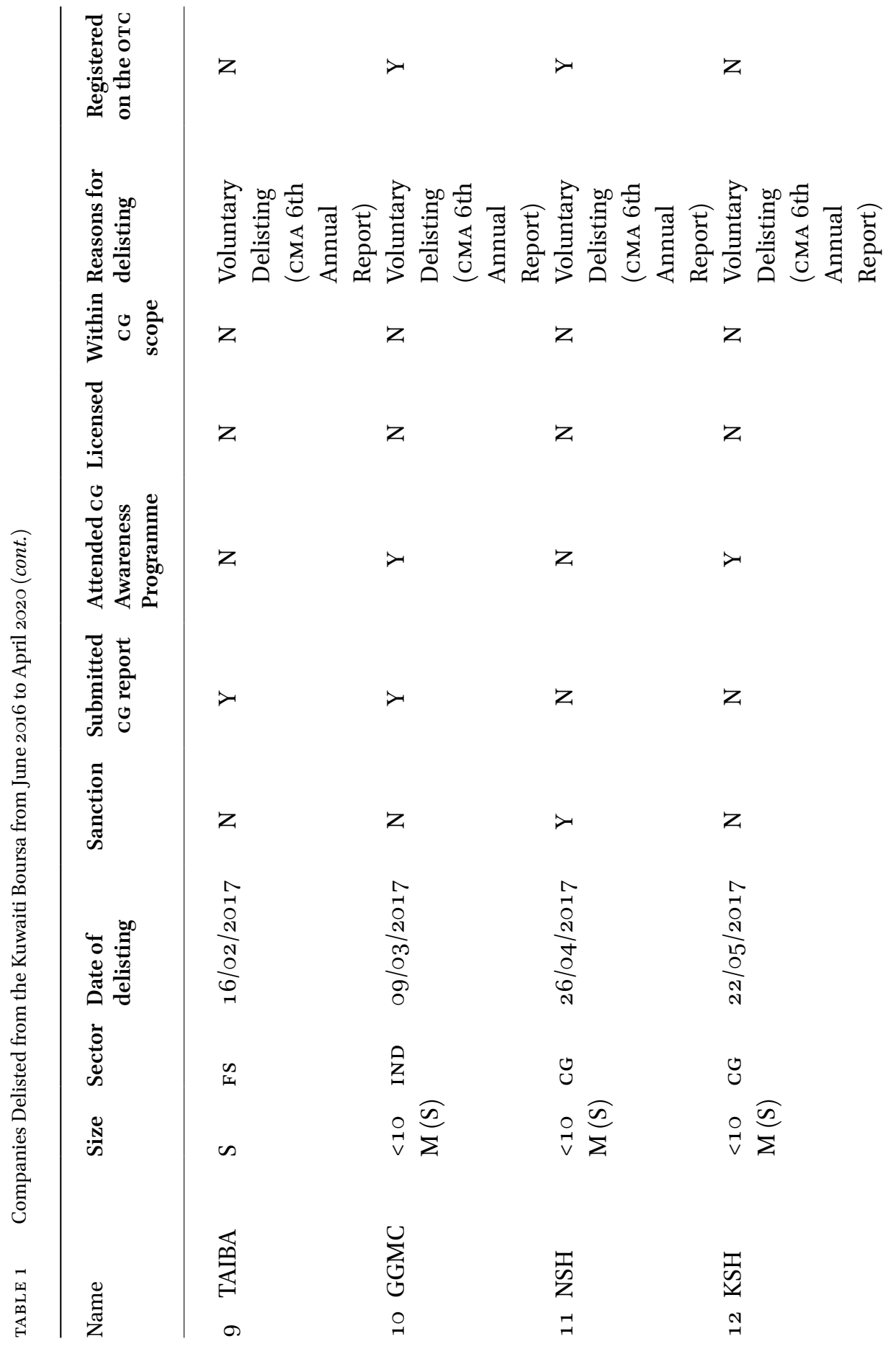




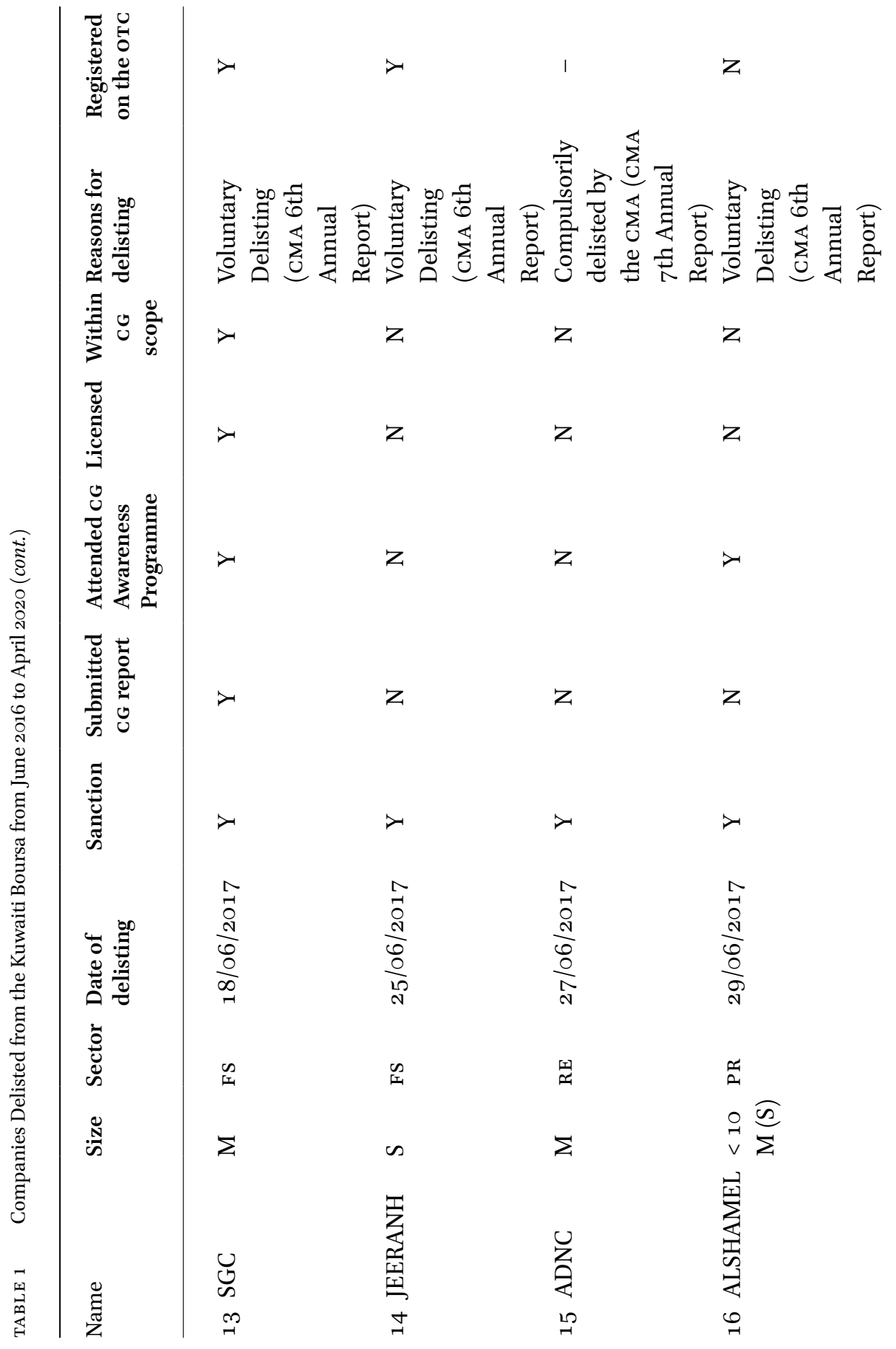




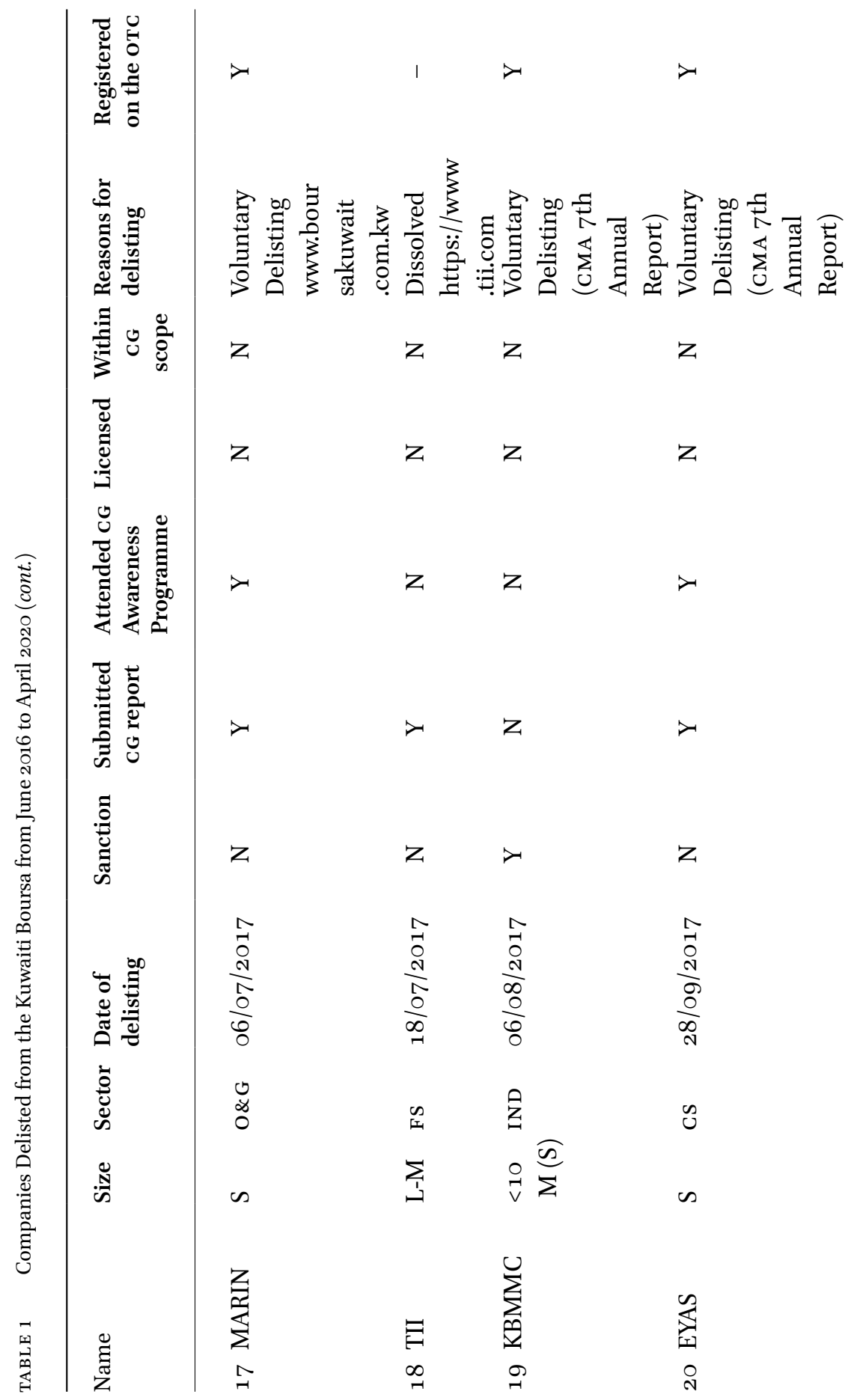




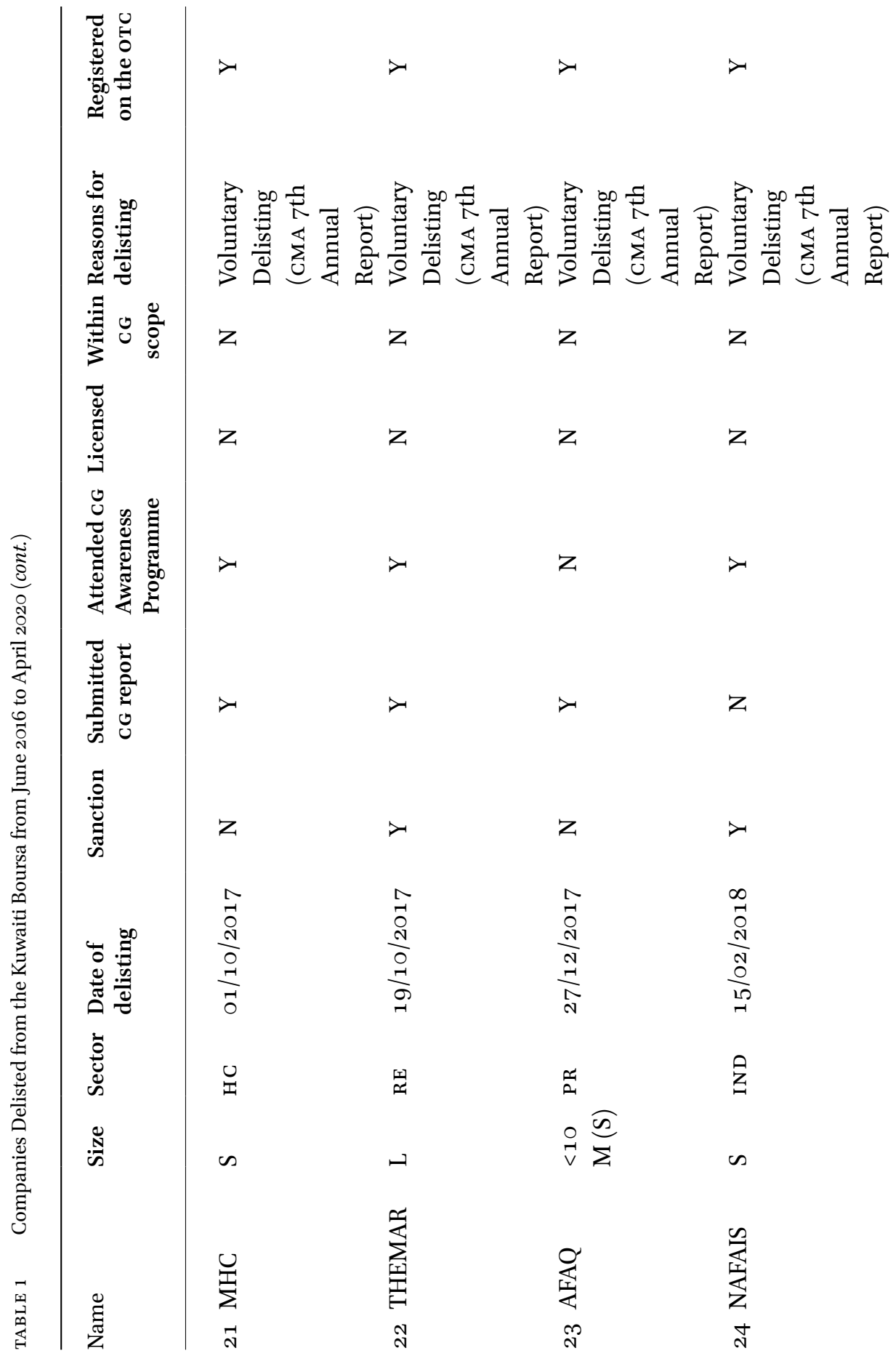




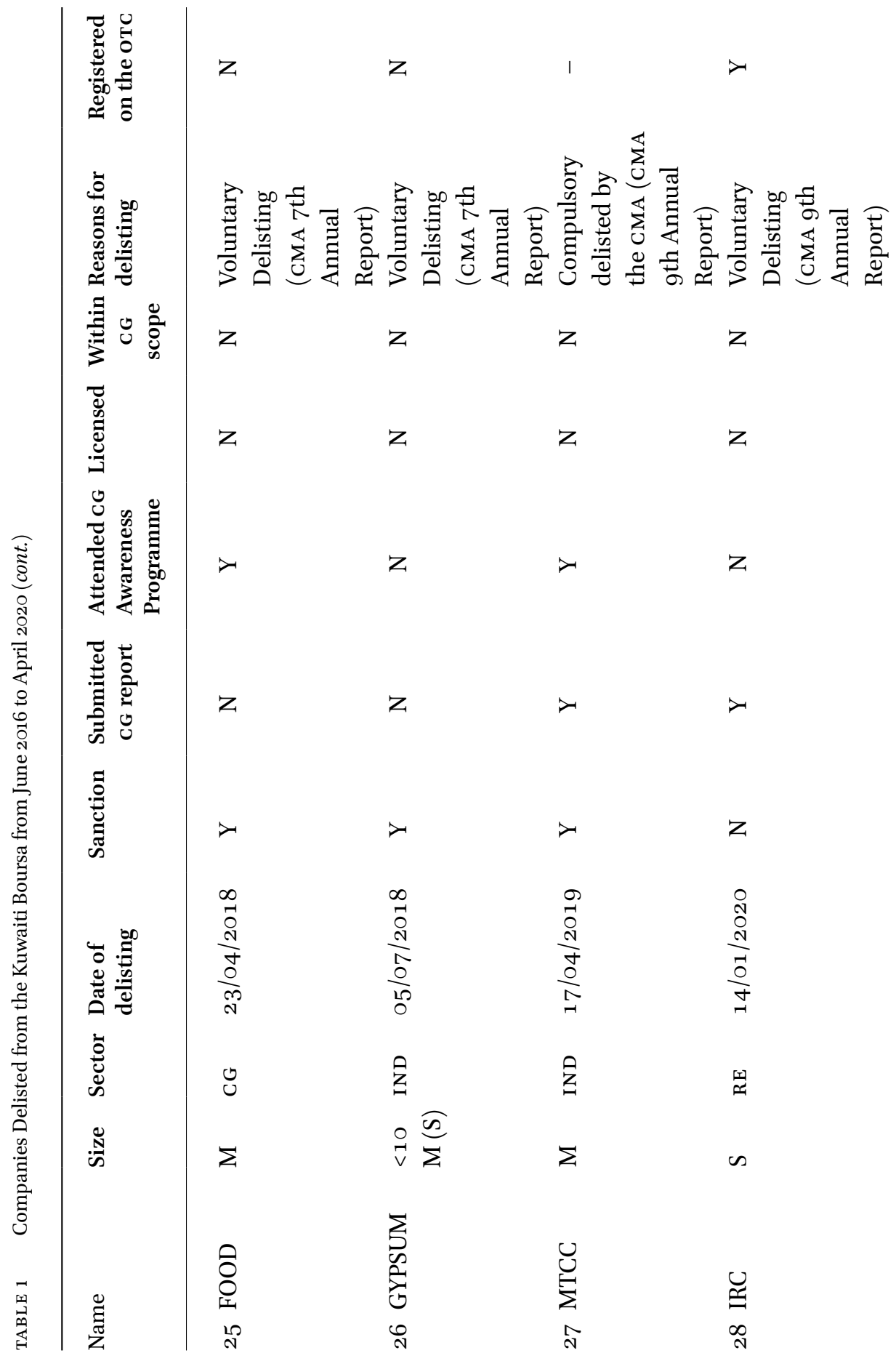




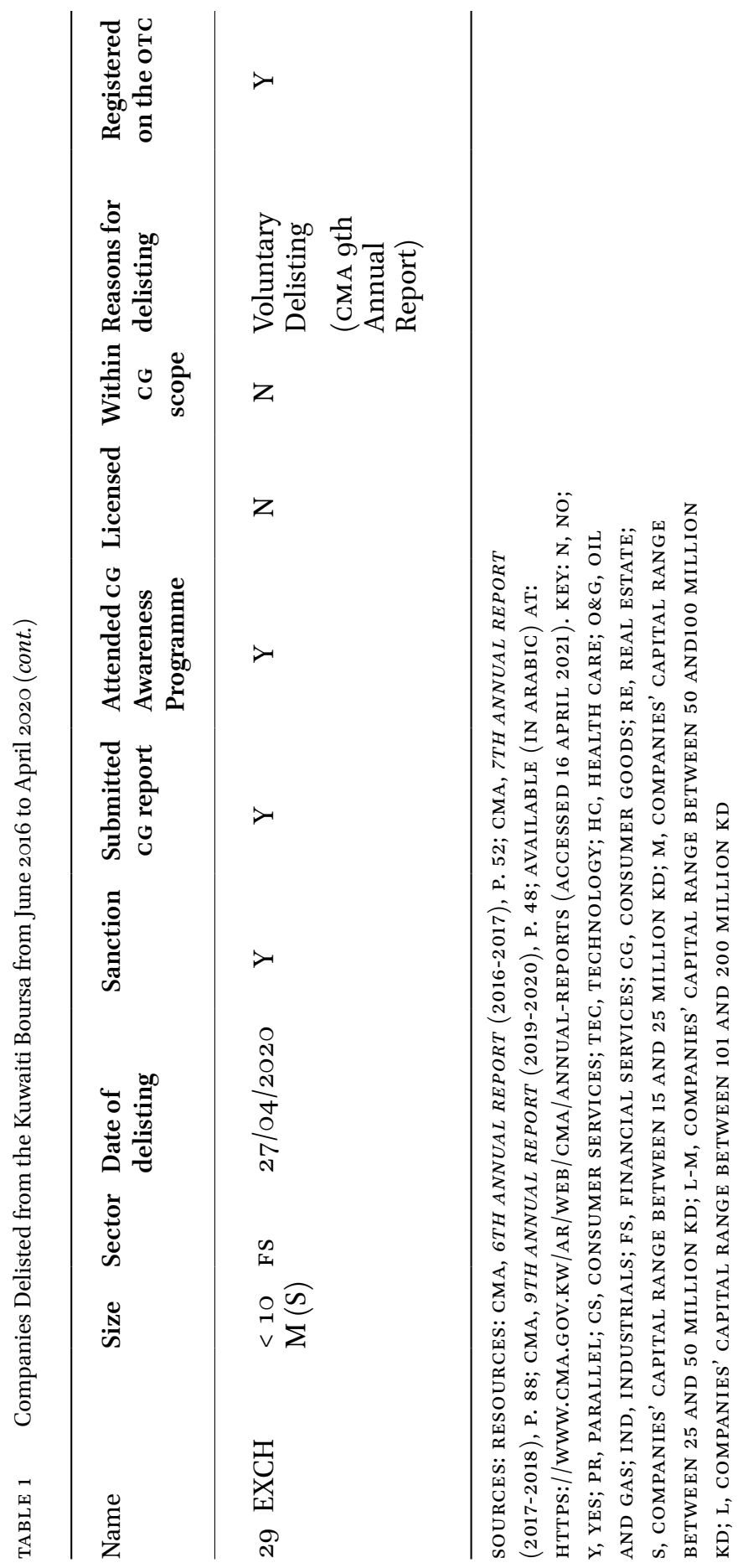


the KCCG 2015 came into force on 30 June $2016 .^{44}$ This report had to be submitted via an online system called eGovernance no later than 10 July $2016 .{ }^{45}$ According to the list, 11 companies in the sample did not comply with the CMA requirement. ${ }^{46}$ These 11 companies represent $39 \%$ of the total delisted companies. However, 10 of them voluntarily delisted, while one company, ADNC, ${ }^{47}$ was delisted by a CMA resolution. ${ }^{48}$ Thus, $38 \%$ of voluntarily delisted companies did not submit the $\mathrm{CG}$ report.

b. The disciplinary board in the CMA may issue penalties in cases where the rules, regulations, decisions, or instructions issued by the Authority are violated ${ }^{49}$ However, MTCC was sanctioned with a warning for violating Anti-Money Laundering and Combating Terrorism, and Ongoing Client Due Diligence and Unusual Transactions modules. ${ }^{50}$ The financial penalties ranged from 1,000 to $5^{0,000} \mathrm{KD}$ for different violations. ${ }^{51}$ Accordingly, companies were penalised for violating the provisions of different modules, such as listing rules, security activities and registered persons, client funds and client assets, dealing in securities, conduct of business,

CMA issued a reminder announcement to submit the report on time before the Code came into force, available online at https://www.cma.gov.kw/en/web/cma/cma-board -releases/-/cmaboardreleases/detail/434827 (accessed 16 April 2021. Finally, the submission process is electronic and easy to follow, so companies need not spend time on handing the required papers - the report is submitted by 'eGovernance', which enables companies to upload the report electronically. Thus, it is worthwhile giving this list consideration to evaluate company compliance levels with the new Corporate Governance Code. The list is available online at https:/www.cma.gov.kw/en/web/cma/cma-board -releases/-/cmaboardreleases/detail/438433 (accessed 16 April 2021).

44 Available online at https:/www.cma.gov.kw/en/web/cma/cma-board-releases/-/cma boardreleases/detail/438433 (accessed 16 April 2021).

45 Ibid.

46 Available online at https://www.boursakuwait.com.kw/en/securities/company-infor mation/delisted-companies (accessed 16 April 2021).

47 Al-Dar National Real Estate Co. (KSC).

48 A copy of the decision is available (in Arabic) at: https://s3-eu-west-1.amazonaws .com/content.argaam.com/21dcb845-322e-4e8d-ad89-a59032ecac3b.pdf (accessed 16 April 2021).

49 Law No. 7 of 2010 Regarding the Establishment of the Capital Markets Authority and Regulating Securities Activities and its Amendments (2010), Articles 139 and 146.

$5^{\circ}$ Available online at https://www.cma.gov.kw/en/web/cma/cma-board-releases/-/cma boardreleases/detail/46oo31 (accessed 16 April 2021).

$5^{1}$ Available online at https://www.cma.gov.kw/en/web/cma/cma-board-releases/-/cma boardreleases/detail/488616; https:/www.cma.gov.kw/en/web/cma/cma-board-releases /-/cmaboardreleases/detail/488317 (accessed 16 April 2021). 
disclosure and transparency, and corporate governance. ${ }^{52}$ Twelve companies, $41 \%$ of the total number of delisted companies, were penalised by the CMA. However, 10 of them voluntarily delisted while two companies (ADNC and MTCC), ${ }^{53}$ were delisted by CMA resolution. Thus, about $38 \%$ of voluntarily delisted companies did not comply with the legal requirements.

c. The cMA organised an awareness programme to teach companies subject to the KCCG 2015 about the new requirements. ${ }^{54}$ This programme lasted 2 weeks, from 10 April 2016 to 21 April 2016, and was devoted to companies concerned with complying with CG instructions. ${ }^{55}$ The CMA published the names of the 11 companies which did not attend this programme; this number represents $37.9 \%$ of the total number of delisted companies. ${ }^{56}$ However, 9 companies voluntarily withdrew from the Boursa, whereas ADNC and TII were compulsorily delisted and/or delisted due to liquidation, respectively. Thus, $34.6 \%$ of voluntarily delisted companies did not attend the awareness programme.

2. Examination of the second aspect: alienation from the scope of corporate governance

a. It is important to note that companies licensed by the CMA or listed on the Boursa are required to meet the $\mathrm{CG}$ requirements. According to the CMA list of licensed companies, available on the CMA website, 28 delisted companies in the sample were not licensed by the CMA. ${ }^{57}$ This indicates that $96.5 \%$ of all delisted companies were no longer obliged to comply with the KCCG 2015. Among these, two companies were compulsorily delisted from the market, one

$5^{2}$ For example, the CMA issued financial penalties against SGC, available online at https:// www.cma.gov.kw/en/web/cma/cma-board-releases/-/cmaboardreleases/detail/1018941. Also, see https://www.cma.gov.kw/en/web/cma/cma-board-releases/-/cmaboardreleases /detail/998493 and (in Arabic), https://www.cma.gov.kw/ar/web/cma/cma-board-relea ses/-/cmaboardreleases/detail/630935. The смA also penalised the Ехсн for violating the listing rules: https://www.cma.gov.kw/en/web/cma/cma-board-releases/-/cmaboard releases/detail/640633 (accessed 16 April 2021).

53 Mushrif Trading \& Contracting Co. A copy of the decision (in Arabic) is available online at https://s3-eu-west-1.amazonaws.com/content.argaam.com/21dcb845-322e-4e8d-ad89-a5 9032ecac3b.pdf (accessed 16 April 2021).

Available (in Arabic) at: https://www.cma.gov.kw/ar/web/cma/cma-board-releases/-/ cmaboardreleases/detail/402519 (accessed 16 April 2021).

Ibid.

$56 \quad$ Ibid.

57 Available (in Arabic) at: https://www.cma.gov.kw/en/web/cma/licensed-companies. 
company was dissolved, ${ }^{58}$ and 25 were voluntarily delisted. Thus, $96 \%$ of the voluntarily delisted companies fall outside the scope of corporate governance.

b. Registration on the отс is an important aspect of linking voluntary delisting from the Boursa with the issue of a non-compliance culture. As will be explained further in Sub-section 3.2.2, the оTC is a less restricted market, with no CG requirements. ${ }^{59}$ The отC website indicates that 19 companies, representing $65 \%$ of companies in the sample, are registered on the отс. ${ }^{60}$ All 19 are companies that have voluntarily delisted. Thus, $73 \%$ of the companies that voluntarily delisted are on the отс.

\subsubsection{Observations}

Despite the limited information available regarding this matter, it appears that a substantial number of the voluntarily delisted companies in the sample were sanctioned by the CMA for violating different legal requirements, including the main one for assessing the competence of the $\mathrm{CG}$ approach: i.e., submitting a CG report. Because the success of this approach relies on the companies themselves and other business parties to act with integrity in applying the code,${ }^{61}$ it is difficult to assess the KCCG 2015 due to the lack of GC reports. Also, a substantial number of voluntarily delisted companies did not attend the CMA Awareness Workshop, which was one of the CMA's efforts to educate companies about corporate governance. However, some companies were not interested. Thus, most of the voluntarily delisted companies were lacking in discipline and education about CG requirements.

Three companies (MHC, EYAS and IKARUS) in the sample stated 'difficulty in complying with the CG rules' as one of the reasons for delisting from the Boursa. ${ }^{62}$ However, this research claims that a non-compliance culture exists

58 Available online at https://www.mubasher.info/news/3215435/-المستثمر-الدولي-تقترح ?

59 CMA, 8th Annual Report (2018-2019), p. 40.

6o Available online at https://www.boursakuwait.com.kw/ar/otc-platform/platform-partici pants/companies (accessed 16 April 2021).

61 David Seidl, Paul Sanderson \& John Roberts, Applying 'Comply-or-Explain': Conformance with Codes of Corporate Governance in the UK and Germany, Working Paper No. 389 (2009), p. 4.

62 Ahmad Awad, AGM IKARUS agrees to withdraw from the Kuwaiti Boursa, available online

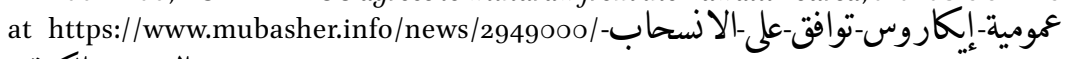
courrentUserCountryCode=GB (accessed 16 April 2021); Almowazi, Withdrawal of EYAS for Academic and Technical Education from the Stock Exchange 
across all voluntarily delisted companies rather than claiming that this is the main reason why some companies delist. For example, the Board of Directors of GYPSUM announced that the company was voluntarily delisted because it was unable to raise its capital to 10 million KD and increase its number of shareholders to 200 and that the trading level on its shares was low. ${ }^{63}$ Still, because GYPSUM did not submit a CG report, it was sanctioned with a warning. ${ }^{64}$ The company was also fined at least 1,00o KD for not establishing a risk management office and an internal audit office in accordance with CG requirements. ${ }^{65}$ Thus, the delisted companies were not fully complying with the rules due to the existence of a non-compliance culture.

It also appears that a substantial number of voluntarily delisted companies were not licensed by the CMA, and, therefore, were outside the scope of corporate governance. Most importantly, many voluntarily delisted companies are now registered on the отс. The conclusion could be drawn that their withdrawal could be linked to a non-compliance culture. The prevalence of such a culture is an important aspect in calling for the adoption of a CG change. This would be especially important because, if a proper change is not introduced, this culture will continue to reflect the flows in the CG system.

\subsection{Deficiencies in the Legal Framework of Corporate Governance}

As demonstrated earlier, the CG legal framework in Kuwait relies on the Kuwaiti Companies Law of 2016 and the CMA Executive Bylaws (most importantly Module 15, KCCG 2015) as a main resource and guideline for CG best practices. Yet the continuous voluntary delisting of companies indicates deficiencies in the CG legal framework.

\subsubsection{Deficiency in the Code Approach}

Recalibration of CMA's enforcement of the CG code from a 'binding' to a 'mixed' approach based on a 'comply or explain' concept could be considered a 'good step' toward effective corporate governance. As shown in Figure 3, $27 \%$ of

on 28 September 2017, available online at https://www.almowazi.com/NewsDetails. aspx?ID=34888; Alqabas, AGM of MHC agrees on Voluntary Withdrawal from the Kuwaiti

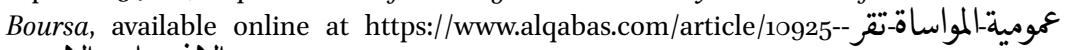
(الانسحاب-الاخت (accessed 16 April 2021).

63 Mubasher.info, "The Board of Directors of "Gypsum" Recommends Withdrawal from the مجلس - Kuwaiti Boursa', available online at https://www.mubasher.info/news/3163992

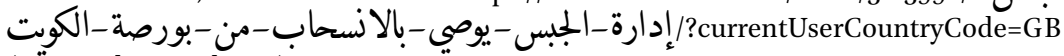
(accessed 16 April 2021).

64 Available online at https://www.cma.gov.kw/en/web/cma/cma-board-releases/-/cma boardreleases/detail/447898 (accessed 16 April 2021.

65 Available online at https://www.cma.gov.kw/en/web/cma/cma-board-releases/-/cma boardreleases/detail/488616 (accessed 16 April 2021). 


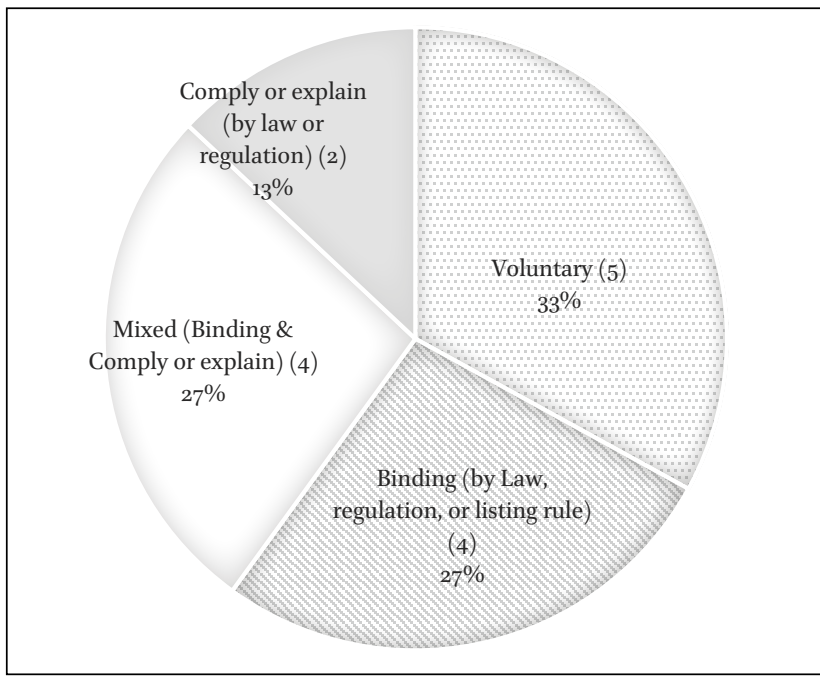

FIGURE 3 Implementation Mechanisms for the Corporate

Governance Framework.

SOURCE: OECD SURVEY OF CORPORATE GOVERNANCE

FRAMEWORKS MIDDLE EAST SND NORTH AFRICA, OECD (2019), AVAILABLE ONLINE AT HTTPS://WWW .OECD.ORG/DAF/CA/OECD-SURVEY-OF-CORPORATE -GOVERNANCE-FRAMEWORKS-MENA-2019.PDF

(ACCESSED 16 APRIL 2021), P. 14

countries in the Middle East region have adopted the mixed approach, including Kuwait, Saudi Arabia, the UAE DIFC, and Palestine. Hence, the mixed approach is well known in the Middle East region. However, as demonstrated earlier, many companies are still removing themselves from the Boursa. The continuous trend to delist voluntarily indicates that there are many flaws in Kuwait's CG approach.

First, the current adoption of the approach does not differentiate between small- to medium-sized companies and large companies. The KCCG 2015, similarly to KCCG 2013, does not provide different provisions for different company sizes. This distinction was not well considered in the former code since it was apparent that the CMA's Report downplayed voluntary withdrawal because it only included small- to medium-sized companies. ${ }^{66}$

Unfortunately, the CMA again neglected to consider company size when drafting the current code, contradicting the idea of 'one size does not fit all' that 
aligned with the concept of 'comply or explain'.67 The CMA may need to look at and follow other countries in the MENA region, which have issued CG codes that take into account the differences in the types and sizes of companies. ${ }^{68}$ For example, Morocco regulates companies by issuing separate CG codes to regulate different types of listed companies: namely, small- and medium-sized enterprises (SMEs), family-owned companies, state-owned enterprises (sOEs) and credit establishments. ${ }^{69}$

Second, CMA's role in disclosing the level of company compliance is confusing. The CMA has only once addressed the percentage of companies which fulfil the requirement of the KCCG $2015 .{ }^{70}$ The 6th Annual Report (20162017) reveals that 67 out of 203 companies submitted a GC report, fulfilling its requirements. ${ }^{71}$ This means that $33 \%$ of companies provided a sufficient explanation where there was non-compliance, which is rather a low percentage. Here, the CMA only counted the companies which had submitted a GC report and assigned a percentage that appears to be relatively high, as shown in Table 2. However, it only indicates the decline in the total number of com-

TABLE 2 Companies that submitted a CG Report from 2016 to 2020

\begin{tabular}{llll}
\hline Years & $\begin{array}{l}\text { Companies subject to } \\
\text { KCCG 2015 }\end{array}$ & $\begin{array}{l}\text { Companies submitting an Percentage } \\
\text { CG Report }\end{array}$ & \\
\hline $2016-2017$ & 233 & 203 & 86 \\
$2017-2018$ & 198 & 197 & 99 \\
$2018-2019$ & 196 & 195 & 99 \\
$2019-2020$ & 192 & 191 & 99 \\
\hline
\end{tabular}

SOURCES: CMA, 6TH ANNUAL REPORT (2016-2017), P. 62; CMA, 7TH ANNUAL REPORT (20172018), P. 104; CMA, 8TH ANNUAL REPORT (2018-2019), P. 121; CMA, 9TH ANNUAL REPORT (2019-2020), P. 64, AVAILABLE (IN ARABIC) AT: HTTPs://wWW.CMA.Gov.KW/AR/WEB/ CMA/ANNUAL-REPORTS (ACCESSED 16 APRIL 2021)

panies subject to corporate governance, as shown in Figure 4. The CMA did not provide information on companies that fulfilled all the Report's requirements

67 Andrew Keay, 'Comply or Explain in Corporate Governance Codes: In Need of Greater Regulatory Oversight?', Legal Studies 279(34) (2014): 280.

68 Sabri Boubaker \& Duc Khuong Nguyen, Corporate Governance in Emerging Markets (Berlin/ Heidelberg: Springer, 2014), p. 535.

69 Ibid.

70 CMA, 6th Annual Report (2016-2017), p. 62.

$71 \quad$ Ibid. 


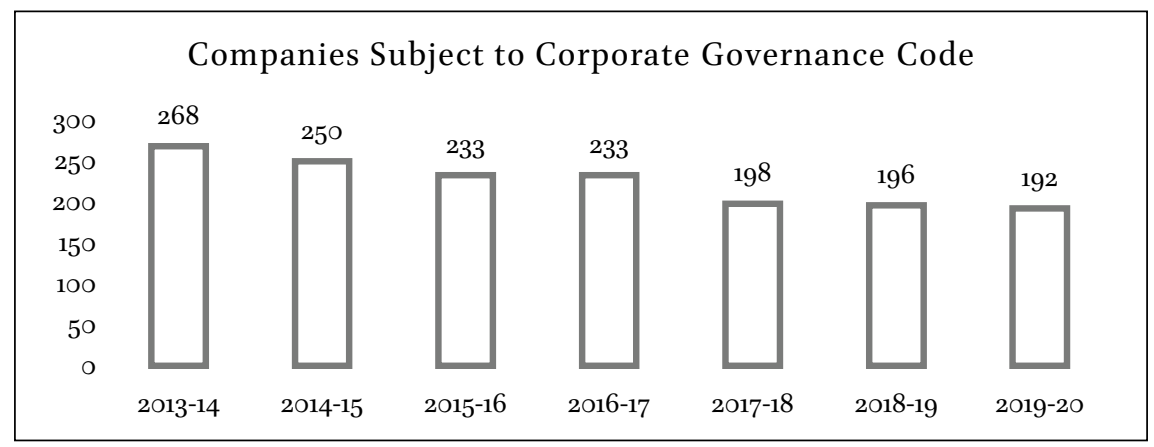

FIGURE 4 Companies subject to the KCCG from 2013 to 2020

SOURCES: CMA, 3RD ANNUAL REPORT (2013-2014), P. 45; CMA, 4TH ANNUAL REPORT (2014-2015), P. 53; CMA, 5TH ANNUAL REPORT (2015-2016), P. 53; CMA, 6TH ANNUAL REPORT (2016-2017), P. 62; CMA, 7TH ANNUAL REPORT (20172018), P. 104; CMA, 8TH ANNUAL REPORT (2018-2019), P. 121; CMA, 9TH ANNUAL REPORT (2019-2020), P. 64, AVAILABLE (IN ARABIC) AT: HTTPS:// WWW.CMA.GOV.KW/AR/WEB/CMA/ANNUAL-REPORTS (ACCESSED 16 APRIL 2021)

according to the forms approved by the CMA in their later annual reports. This results in a shortcoming in the available statistics, indicating a difficulty in evaluation if the approach is functioning effectively in practice. ${ }^{72}$ Thus, it casts doubt on whether the approach is effective.

Third, and perhaps most importantly, the approach does not appear flexible enough to recognise the existing non-compliance culture that prevails among delisted companies in Kuwait, as seen in the cMA Report and the sample examined in this research. Within this culture, companies prefer to be removed from any financial and/or legal obligations imposed by the regulatory and supervisory authorities of stock markets. ${ }^{73}$ This includes disclosure of their material information and provision of financial statements in accordance with 'Module 10: Disclosure and Transparency', paying subscription fees, and adhering to the CG rules. ${ }^{74}$ This leads to companies exiting from the Boursa and, instead, choosing to be on the отс, a stock exchange with no CG requirements. ${ }^{75}$ As demonstrated in Fig. 4, since the adoption of the new KCCG in 2015 until 2020, 41 companies have delisted from the Boursa and moved beyond the scope and rules of KCCG 2015. Compare that number to the

\footnotetext{
$72 \quad$ Keay, supra note 67 at 284.

73 Video_Workshop, supra note 11 at 17:48-17:56.

74 Ibid., 17:58-18:06.

75 CMA, 8th Annual Report (2018-2019), p. 40.
} 
35 companies that delisted and moved beyond the scope of the former KCCG 2013. This shows that the problem of companies removing themselves from the market has become more serious, yet this is not recognized within the current approach. Thus, it raises concerns about the effectiveness of the approach in fulfilling its aims.

It is plausible to suggest that Kuwait should adopt a 'gradual regulatory tightening', similar to other regional countries, such as Saudi Arabia and Egypt. ${ }^{76}$ Such an approach aims to raise the awareness of listed companies, as well as to cultivate the sophistication of governance rules. ${ }^{77} \mathrm{~A}$ gradual regulatory tightening occurs when the regulator starts with a more flexible approach-in Kuwait's case a fully voluntary approach by the CG - and then revises the code to be more mandatory over time. ${ }^{78}$ This approach could help deal with the culture of companies that prefer to be in a less restricted market.

\subsubsection{Fragility of the KCL Provisions}

One of the most evident deficiencies of the CG system that manifested itself in the voluntary delisting phenomenon is the increasing number of voluntarily delisted companies that are registered on the отс. The отс is an automated platform for trading unlisted securities organised by the Boursa, which was also a listed company on the отс until September 2020.79 The CMA and the Boursa do not require companies on the platform to follow disclosure requirements or other instructions-including corporate governance-imposed on companies whose shares are traded on the Boursa. ${ }^{80}$ Therefore, the CMA recommends that investors take sufficient care to study the feasibility of investing in the shares of these companies before making any investment decisions due to the risks that may surround the process of trading on this platform. ${ }^{81}$

Despite the fact that companies registered on the отс are outside the scope of CG application, they should follow CG rules stated in the KCL as the main source of corporate best practice. This research contends that the KCL has its shortcomings, encouraging companies to exit the market and register on the

\footnotetext{
76 Boubaker \& Nguyen, supra note 68 at 543.

77 Ibid.

78 Ibid.

79 Kuwait, отC Trading Rules (2019), Article $3^{-1}$, available online at https://cis.boursa kuwait.com.kw/Portal/BoursaReports/BK_PR_2019_E_136201912570525.pdf (accessed 16 April 2021), https://www.boursakuwait.com.kw/ar/participants/participants/listed -companies (accessed 28 June 2021).

8o CMA, 8th Annual Report (2018-2019), p. 40.

$81 \quad$ Ibid.
} 
отс. This could be linked with the question of why companies are benefiting from listing in the отс more than in the Boursa?

First, many companies on the отC have been able to take advantage of the poor supervisory role of the Ministry of Commerce and Industry in implementing the law. Two events strengthen this argument. (a) The KCL has authorised the supervisory bodies to adopt their CG code since 2012. ${ }^{82}$ Yet, the Ministry has not drafted a code to regulate companies registered on the отс. (b) The law requires the Ministry to invite the general meeting of a company to convene within 15 days in cases where the board fails to call a meeting for any reason. ${ }^{83}$ That two sampled companies, MTCC and ADNC, were delisted due to failing to call their general meetings casts doubt on the role of the Ministry. ${ }^{84}$ Thus, companies can take advantage of the inadequate supervision of the отс.

Second, under the KCL, companies are not obliged to follow many CG requirements, such as (a) requiring independence, qualifications, experiences, and technical skills in directors; ${ }^{85}$ (b) appointing auditors licensed by the $\mathrm{CMA}^{; 6}$ (c) forming a risk management committee; 87 (d) assigning an independent expert such as an asset valuator or investment advisor, which is not compulsory in cases where a transaction between the company and any related party equals $10 \%$ or more of the total assets; 88 (e) developing a system for ensuring timely and high-quality disclosure and transparency, ${ }^{89}$ such as developing mechanisms of presentation and disclosure, including providing all stakeholders with access to timely and transparently disclose data and creating a website page about corporate governance in order to share new data and communicate with shareholders, investors, and stakeholders; ${ }^{90}$ or (f) most importantly, following the mandatory standard under the KCCG 2015 to protect shareholders' rights. ${ }^{91}$ Companies on the отс need not follow any such provisions, including the shareholders' right to all data set out in the disclosure

\footnotetext{
$82 \quad$ Kuwaiti Companies Law No. 1 (2016), Articles 186 and 187.

83 Ibid., Article 207.

84 A copy of the мтсc delisting decision is available (in Arabic) at: https://s3-eu-west-1 .amazonaws.com/content.argaam.com/21dcb845-322e-4e $8 \mathrm{~d}-\mathrm{ad} 89-\mathrm{a} 59032 \mathrm{ecac} 3 \mathrm{~b}$ .pdf and the ADNK delisting decision at: https://cis.boursakuwait.com.kw/Portal/News PDF/28620178205523004382.pdf (accessed 17 April 2021).

85 Kuwait, CMA, Executive Bylaws, Module 15, Corporate Governance (2015), Article 2-3.

86 Ibid., Article 5-8.

87 Ibid., Article 6-4.

88 Ibid., Article 7-7.

89 Ibid., Article 8-1.

$90 \quad$ Ibid., Articles 8-8 and 8-5.

91 Ibid., Chapter 9, Rule viII: Respect the Rights of Shareholders, from Article 9-1 to Article 9-10.
} 
record of the board members and the executive management. ${ }^{92}$ That, of course, hinders the monitoring role of the company's shareholder.

Third, another shortcoming in the KCL is the fragility of the provisions concerning the responsibility of the board of directors, especially those related to the duty of loyalty. Under the KCL, a board director can engage in self-dealing or have a conflict of interest if they receive approval from the general assembly, which can also waive a director's duty to not compete with the company's business. ${ }^{93}$ This legal fragility raises two main concerns. First, when there is concentrated ownership in the hands of major shareholders, the approval around breaking these liabilities is very feasible. Second, general assembly meetings are only held on an annual basis, leaving a large gap for shareholders to monitor the board of directors. ${ }^{94}$ This can foster an irresponsible corporate attitude of a board misusing its power, including breaching the duty of loyalty towards the company. ${ }^{95}$ This structure reinforces the idea that the responsibilities of the board of directors are not well described in the regulations of the MENA countries. ${ }^{96}$

Overall, these shortcomings could imply that the KCL does not prevent the domination of a board of directors over its company, but instead provides the perfect environment for a concentration of share ownership, which negatively affects the role of ownership structure as a CG mechanism. This argument is discussed below.

\subsection{Concentration of Ownership}

The ownership structure is an important element when it comes to delisting, as companies with concentrated ownership and less tradable shares in a less liquid national market tend to withdraw. ${ }^{97}$ This is applicable to the Kuwaiti context as the voluntary delisting problem indicates that the concentration of ownership is one of the defining characteristics of the Kuwaiti stock market. Suggestions from the CMA Report and the sample of delisting companies are consistent with the same idea. There are many obstacles to implementing a CG

$92 \quad$ Ibid., Article 9-9, Point 7.

93 Kuwaiti Companies Law No. 1 (2016), Articles 197 and 199.

94 Ahmed al-Melhem, Kuwaiti Companies Act: A Comparative Study (Part One), 2nd edn. (Kuwait: University of Kuwait: Acadamic Publication Council, 2014), p. 373.

95 Al-Melhem, ibid., p. 376.

$96 \quad$ Amico, supra note 1 at 37 and 38.

97 Steen Thomsen \& Frederik Vinten, Delistings in Europe and the Costs of Governance, available online at https://papers.ssrn.com/sol3/papers.cfm?abstract_id=9866o3 (accessed 2 April 2021). 
system in Kuwait. ${ }^{98}$ It has been argued that the Kuwaiti system does not readily support good CG mechanisms. ${ }^{99}$ For example, the ownership structure is highly concentrated in the hands of a few major shareholders, and this creates problems for listed companies and shareholders. ${ }^{100}$ This type of ownership structure raises several concerns.

First, the concentrated ownership in Kuwait, along with the simple legal requirements, has encouraged large shareholders to exploit the law, which can negatively affect minority rights. The 2016 CMA Report looked at 17 companies that voluntarily delisted and found that an average of three owners held more than $51 \%$ of the total shares in each of the companies. ${ }^{101}$ This gave these majority shareholders - or as the CMA calls them 'the dominant groups'- the power to control substantial decisions in the company, including withdrawing from the market. This is particularly so given that the CMA Executive Bylaws only require the approval of an ordinary general meeting for a company to delist from the market rather than the approval of the owner of at least $75 \%$ of the capital, which is the required approval for an extraordinary general meeting. ${ }^{102}$ This rule results in companies with 'dominant groups' having absolute power as it allows them to escape the strictures of the market easily. This legal situation removes a company's ownership structure as an effective mechanism of corporate governance. However, in 2021, the CMA fixed this problem by amending this rule, which now requires the approval of no less than $75 \%$ of the attendees of the general assembly for future companies seeking to voluntarily delist from the Boursa. ${ }^{103}$ This step was necessary to make it more difficult for companies to exit from the market.

Second, the high concentration of ownership in listed companies in Kuwait has created an agency problem between large shareholders and small shareholders. ${ }^{104}$ Looking to Table 3 , the total concentration of ownership in Kuwait companies ranged from $46 \%$ to $43 \%$ during 2017 to 2020 . And this is attributed to three major shareholder types, namely, institutional shareholders, the

98 Mejbel al-Saidi \& Bader al-Shammari, 'Corporate Governance in Kuwait: An Analysis in Terms of Grounded Theory', International Journal of Disclosure and Governance 128(11) (2014): 128-16o, at 129 .

$99 \quad$ Ibid., p. 129.

100 Ibid.

101 PowerPoint_Workshop, supra note 12 at slide 14.

102 Kuwait, CMA, Executive Bylaws, Module 12: Listing Rules (2015), Article 5-2.

103 Resolution No. 16 of 2021, available online at https://www.cma.gov.kw/documents /20622/1024994/Translation+of+Module+Twelve+Amendments+-Post+Board+-+11.2 .2021.pdf/1a2d295d-666o-48f3-8d51-d3df44420210 (accessed 16 April 2021).

104 Rafael La Porta, F. Lopes-de-Silanes, A. Shleifer \& R. Vishny, 'Law and Finance', Journal of Political Economy 106(6) (1998): 1113-1155; Al-Saidi \& Al-Shammari, supra note 98 at 134. 
TABLE 3 Ownership structure for companies in the Kuwait Boursa, 2017-2020 (according to shareholding value at the end of the year)

\begin{tabular}{lrrrr}
\hline Group & $\mathbf{2 0 1 7}$ & $\mathbf{2 0 1 8}$ & $\mathbf{2 0 1 9}$ & $\mathbf{2 0 2 0}$ \\
\hline Government & $13 \%$ & $14 \%$ & $15 \%$ & $15 \%$ \\
Private institutions & $30 \%$ & $26 \%$ & $24 \%$ & $24 \%$ \\
Families (individuals) & $3 \%$ & $3 \%$ & $3 \%$ & $4 \%$ \\
Total concentration & $46 \%$ & $44 \%$ & $42 \%$ & $43 \%$ \\
Minority shareholders & $54 \%$ & $56 \%$ & $58 \%$ & $57 \%$ \\
\hline
\end{tabular}

SOURCE: WWW.BOURSAKUWAIT.COM.KW AND WWW.ALJOMAN.NET

government, and dominant families (individuals). ${ }^{105}$ In the years from 2017 to 2020 , the first category of major shareholders was the institutional investor of a total concentration from $30 \%$ to $24 \%$. That is consistent with the latest studies. For example, in 2019, an OECD survey concluded that Kuwait had a significant level of institutional ownership in comparison to other GCC countries. ${ }^{106}$ This was due to the large number of investment companies holding a large number of shares in other listed companies. ${ }^{107}$ Hence, institutional investors play a significant role in the Kuwaiti market.

Furthermore, Table 3 shows that government shareholdings increased from $13 \%$ to $15 \%$ from 2017 to 2020 , whereas family shareholdings stabilised during the same period from $3 \%$ to $4 \%$, which support that these ownerships are significant in the Kuwait market. ${ }^{108}$ A study conducted in 2009 indicated that institutional shareholders own large shares of companies in the following sectors: services $(17.23 \%)$, banking $(28.7 \%)$, and manufacturing $(28.05 \%) .{ }^{109}$ Meanwhile, Kuwait government ownership is mainly concentrated in sectors

105 Bader al-Shammari, Philip Brown \& Ann Tarca, 'An Investigation of Compliance with International Accounting Standards by Listed Companies in the Gulf Co-Operation Council Member States', International Journal of Accounting 43(4) (2008): 425-447.

106 OECD, OECD Survey of Corporate Governance Frameworks Middle East snd North Africa, $O E C D$ (2019), available online at https://www.oecd.org/daf/ca/OECD-Survey-of-Corporat e-Governance-Frameworks-MENA-2019.pdf (accessed 16 April 2021), at 10.

107 Al-Shammari, Brown \& Tarca, supra note 105, at 110; Al-Saidi \& Al-Shammari, supra note 98 at 132 .

108 Ibid.

109 Mohammad al-Mutairi, Corporate Finance Decisions, Governance, Environmental Concerns and Performance in Emerging Markets: The Case Study of Kuwait, Doctoral Dissertation, Faculty of Commerce, University of Wollongong, Wollongong, NSw, 2011, p. 68. 
such as manufacturing $(11.5 \%)$, services $(11.22 \%)$ and investments $(10.75 \%) .{ }^{110}$ The government also owns shares in insurance (7.06\%) and food $(8.57 \%) .{ }^{111}$ With regard to the dominant families, the study shows that family groups concentrate on holding shares in banking $(27.10 \%)$ and manufacturing (16.07\%) sectors, while individual investors have substantial equity in sectors such as investments $(58 \%)$, food $(58.01 \%)$, insurance $(57.05 \%)$, and real estate $(55.15 \%) .{ }^{112}$ The concentration of ownership in the hands of large shareholders, such as the government, dominant families, and institutional investors, raises the issue of an agency problem between groups of large shareholders and minority shareholders. ${ }^{113}$ It means that the separation of ownership and control does not apply in Kuwait as in other emerging markets; instead, conflicts of interests arise between the major and minor shareholders. ${ }^{114}$ Third, the group of major shareholders which possess the majority of shares plays a different role in corporate governance. Despite this role, most of them negatively affect the practice of corporate governance. This is supported by a study based on a sample of 134 companies listed on the Kuwait Stock Exchange ${ }^{115}$ (KSE) in 2010.116 The study examined the influence of institutional and government ownership as corporate governance mechanisms on firm performance. ${ }^{117}$ On the one hand, the findings of the study indicate a positive relationship between institutional investor shareholding and firm performance in KSE, implying that institutional ownership is an effective and powerful CG mechanism. ${ }^{118}$ On the other hand, the study found that there was a negative relationship between government shareholding and firm performance, implying a poor performance when the government acquired shares; it also justifies

\footnotetext{
110 Ibid.

111 Ibid.

112 Ibid.

113 Mohammed M. Omran, Ali Bolbol \& Ayten Fatheldin, 'Corporate Governance and Firm Performance in Arab Equity Markets: Does Ownership Concentration Matter?', International Review of Law and Economics 28(1) (2008): 32-45, at 33.

114 Mohammad E. al-Wasmi, Corporate Governance Practice in the GCC: Kuwait as a Case Study, Doctoral Dissertation, Law School, Brunel University, London, 2011, p. 36.

115 The Kuwaiti Boursa was founded in April 2014 by the Capital Markets Authority, replacing the Kuwait Stock Exchange (KSE) to become the nation's official exchange, effective on 25 April 2016. Thus, after 2014, the KSE name was changed to become the Kuwait Boursa. After 2019, the Boursa was partially privatised. For more information, see: https://www .boursakuwait.com.kw/en/history (accessed 16 April 2021).

116 Mishari Alfaraih, Faisal Alanezi \& Hesham Almujamed, 'The Influence of Institutional and Government Ownership on Firm Performance: Evidence from Kuwait', International Business Research 5(10) (2012): 192-200.

117 Ibid.

118 Ibid.
} 
the view that the government tends to have political motivations rather than commercial motivations in managing businesses. ${ }^{119}$ This raises the concern that the government plays no effective role in monitoring its own companies. ${ }^{120}$

Importantly, the boards of most companies in Kuwait are mainly controlled by large shareholders or families. ${ }^{121}$ Additionally, most companies have a member of the dominating family as the CEO, as the chairman of the board, and as a non-executive director. ${ }^{122}$ This has a bearing on voluntary delisting. For example, EXCH voluntarily delisted from the Boursa due to the concentration of $81 \%$ of the total shares in the hands of a single family, as it had $100 \%$ of the board's representation. ${ }^{123}$ This supports the idea that single families control the boards of most listed companies in Kuwait. ${ }^{124}$ The father takes the position of chairman of the board and, at the same time, his son or another family member takes the position of the CEO. ${ }^{125}$ That, of course, raises the concern that controlling families chose unqualified board members because they tend to select their friends and family members. ${ }^{126}$ That also supports the finding that legal frailty is empowering large shareholders to concentrate their ownership to protect their interests and wealth. ${ }^{127}$ Hence, this is why each type of ownership has a different influence as a CG mechanism. ${ }^{128}$ That is why block holders are the main players in improving corporate governance in emerging markets, including Kuwait. ${ }^{129}$

Fourth, the concertation of ownership raises the concern of the existence of owner-managed companies, which is a common CG issue in emerging markets. ${ }^{130}$ This means that the large shareholders or the founders are in

119 Ibid., p. 198.

120 Ibid.

121 Mejbel al-Saidi, Corporate Governance and Firm Performance: The Case of Kuwait, Doctoral Dissertation, Faculty of Business \& Law, University of Portsmouth, Portsmouth, 2010, as cited by Al-Saidi \& Al-Shammari, supra note 98 at 131.

122 Ibid.

123 Alqabas, 'EXCH Approves the Withdrawal from the Boursa', available online at https:// alqabas.com/article/656057-صيرفة-تقر-الانحاب-من-البورصة (accessed 16 April 2021).

124 Al-Saidi, supra note 121, as cited by Al-Saidi \& Al-Shammari, supra note 98 at 132.

125 Ibid.

126 Al-Saidi \& Al-Shammari, supra note 98 at 144.

127 Rafael La Porta, F. Lopes-de-Silanes, A. Shleifer \& R. Vishny, 'Legal Determinants of External Finance', Journal of Finance 52(3) (1997): 1131-115o; Rafael La Porta, F. Lopes-de-Silanes, A. Shleifer \& R. Vishny, 'Investor Protection and Corporate Governance', Journal of Financial Economics 58(1-2) (2000): 3-27; Rafael La Porta, F. Lopes-de-Silanes, A. Shleifer \& R. Vishny, 'Corporate Ownership around the World', Journal of Finance 54 (1999): 471.

128 Alfaraih et al., supra note 116 at 193 .

129 Al-Wasmi, supra note 114 at 43.

$130 \quad$ Ibid., p. 36. 
management. ${ }^{131}$ This is applicable to the Kuwaiti context, as the voting system is based on 'one vote per share', which enables these major shareholders to be 'insiders,' due to their substantial representation on boards. ${ }^{132}$ In practice in Kuwait, whoever owns the majority of the shares becomes the chairman of the board of directors. ${ }^{133}$ If a developing country has insufficient legal protection for outsider shareholders, original shareholders can maintain their influential positions in companies that have resulted from their concentration of ownership. ${ }^{134}$ Consequently, large shareholders are incentivised to step in to protect their interests in their companies. ${ }^{135}$ Therefore, large shareholders can use CG structures to meet their interests, and companies in Kuwait depend on an excessive level of concentrated ownership as a ddriving governance control mechanism.' ${ }^{136}$ While the large shareholders dominate positions on the boards, a minority of shareholders have no sufficient representation in the board room. ${ }^{137}$ That, of course, raises the issue of the role of minority shareholders in management and policy decision-making being diminished. ${ }^{138}$ Large shareholder domination in Kuwaiti companies creates an obstacle for shareholders to have an effective role in the CG scheme, which is discussed below.

\subsection{Passive Shareholders}

Shareholder passivity is a well-recognised problem in MENA countries, and many believe that shareholders are not vigorous in practising their legal rights. ${ }^{139}$ Appling to Kuwaiti context, shareholder passivity is also manifested in voluntary delisting. According to the CMA Report regarding delisting, the rules permit a shareholder or shareholders who own $5 \%$ to $30 \%$ of the company's shares to submit an objection against the resolution of the general assembly. ${ }^{140}$

\footnotetext{
131 Ibid.

132 Al-Saidi \& Al-Shammari, supra note 98 at 132.

133 Ahmed al-Melhem, Companies Act of Kuwait A Comparative Study, Part 2: The Special Rules (Kuwait: Kuwait University: Acadamic Publication Council, 2015), p. 508.

134 La Porta et al., supra note 127.

135 La Porta et al., supra note 127 at 2 and 3.

136 Al-Saidi, supra note 121, as cited by Al-Saidi \& Al-Shammari, supra note 103 at 132.

137 Al-Saidi \& Al-Shammari, supra note 98 at 133.

138 Ibid.

139 Boubaker \& Nguyen, supra note 67 at 531 and 532.

140 Article 3-2-1 of the Executive Bylaws, Module 9: Mergers and Acquisitions states that any shareholder or a number of shareholders whose ownership percentage of shares of a Listed Company is not less than $5 \%$ and not more than $30 \%$ may submit to the Authority individually or jointly an objection of an ordinary or extraordinary general assembly, in accordance with the following conditions: (1) The objection shall be submitted within 15 days from the date of the issuance of the resolution objected to or their knowledge thereof, whichever is longer. (2) The objecting shareholders shall not be among those who
} 
However, the Report explicitly provided that shareholders were reluctant to object to the delisting; this passivity enabled those with the concentration of ownership to make the decision move forward with delisting without resistance. ${ }^{141}$ Thus, lack of shareholder activism in Kuwait have contributed to the increasing number of companies that voluntarily delisted.

This might suggest that shareholder activism could mitigate the situation. In the companies EDU, TAAMEER and HUMANSOFT, shareholders objections to the CMA actually reversed the company's delisting decision. ${ }^{142}$ However, there are two companies in the sample, NAFAIS and MHC, that eventually withdrew despite shareholders objection. ${ }^{143}$ Hence, shareholder engagements are still limited due to the concentrated ownership and the controlled nature of companies. ${ }^{144}$ This could raise the concern that the concentration of ownership has led to a domination of major shareholder over the company, leaving the minority of shareholders with no power. Looking beyond Kuwait at the Middle East region overall, shareholder activism is rare, due to the concentration in the ownership structure, social and legal traditions, and limited foreign ownership. ${ }^{145}$

Shareholder passivity in Kuwait raises two concerns. The first is that changes in corporate governance would be solely by the regulators, which is rather too slow to keep pace with the necessary developments and global trends. The second is that a lack of litigations against the board of directors have made it difficult to define the director's duties. ${ }^{146}$ This leads to no clear conception of the board's legal liability, raising an additional concern that the board does not consider their legal liabilities when making decisions. ${ }^{147}$ The aim of this section is to demonstrate that the problem of passive shareholders in Kuwaiti companies may refer to different reasons, such as those related to legal, cultural and social factors, which will be discussed below.

approved the objected resolution. (3) The objected resolution shall constitute an abuse of minority rights.

141 Video_Workshop, supra note 11 at 23:08-23:12.

142 CMA, 6th Annual Report (2016-2017), p. 63; CMA, gth Annual Report (2019-2020), p. 48, as these companies are still listed in the Boursa, available online at https://www.boursaku wait.com.kw/en/participants/participants/listed-companies (accessed 16 April 2021).

143 CMA, 6th Annual Report (2016-2017), p. 63; CMA, 7th Annual Report (2017-2018), p. 88; these companies are no longer listed in the Boursa, available online at https://www.boursa kuwait.com.kw/en/securities/company-information/delisted-companies (accessed 16 April 2021).

144 Amico, supra note 1 at 41.

145 Ibid., p. 40.

146 Ibid.

147 Ibid. 


\subsubsection{Legal Factors}

It is submitted that legal protections for shareholders is important to induce activism. If the legal system is weak in protecting small shareholders, they will not be motivated to buy shares and in the end ownership becomes concentrated in the hands of dominant large shareholders. ${ }^{148}$ It has been argued that the absence of shareholder activism in Kuwait may refer to several reasons, most importantly the concentration of share ownership and management by large shareholders, the restrictions on the shareholder rights and the high percentage of shareholding required to practicing their rights. ${ }^{149}$ As shown in Fig. 5, the new KCL of 2016 requires shareholder to hold at least $5 \%$ of company's capital, which is rather a high percentage to practice important rights such as discussing matters not included in the agenda of the general meeting and requesting the Ministry to appoint an auditor to conduct an inspection of their investee company. ${ }^{150}$ Another example is that the law requires the shareholders to hold at least $25 \%$ to ask for replacement of the auditor during the year and to dissolve the board of directors or remove its chairman or any one or more of its members. ${ }^{151}$ In light of the high level of concentrated ownership, it is difficult for shareholder to own the required shareholding hence making these provision of the KCL restricting essential tools for shareholders to monitor the board of directors and hold its directors accountable. It is important to discuss in depth the main defects in the Kuwaiti legal system that hinder the role of shareholders in the company, which will be discussed below.

\section{3·4.1.1 Insufficient Protection for Minority Shareholders in Delisted Companies}

In general, minority shareholders have always been considered the most affected group when it comes to delisting. ${ }^{152}$ Withdrawal from the main market is 'the final nail in the coffin for the stock' for minority shareholders. ${ }^{153}$ And, most importantly, it invades the minority right to sell their shares at a profit, which is a constituency part of their property. ${ }^{154}$ This invasion is important to note in the Kuwaiti case, as the cмA Report concluded that voluntary

\footnotetext{
148 Fred Kaen, A Blueprint for Corporate Governance: Strategy, Accountability, and the Preservation of Shareholder Value (New York, NY: Amacom, 2003), p. 24.

149 Al-Wasmi, supra note 114 at 257.

150 Kuwaiti Companies Law No. 1, 2016, Articles 218 and 298.

151 Ibid., Articles 212 and 233.

152 Hamilton v. Nozko [1994] Del Ch. No. 13014 WL 413299 (Del Ch). Regarding the different influence of voluntary delisting on the majority and minority shareholders.

153 Julia Khort, 'Protection of Investors in Voluntary Delisting on the US Stock Market', Uppsala Faculty of Law Working Paper 4 (2014): 1-51, at 4.

154 Ibid., p. 7 .
} 


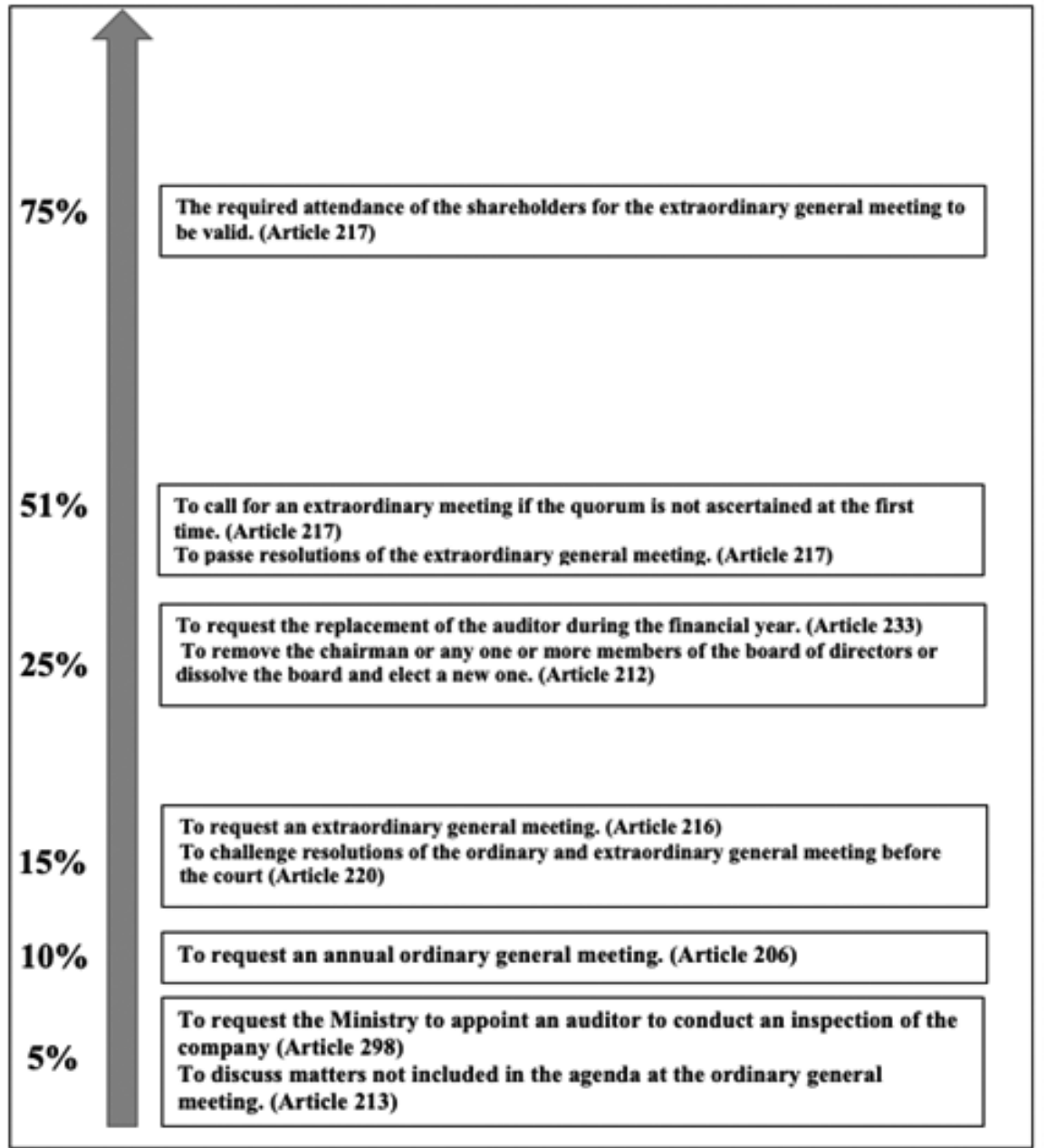

FIGURE 5 Minimum shareholding requirements to shareholders rights under KCL 2016

withdrawal has no negative impacts on the Kuwaiti market but only harms the interest of minority shareholders. ${ }^{155}$ From the CMA perspective, this is mainly because minority shareholders can only sell their shares through the отс market. ${ }^{156}$ That involves risk in the trading process, which is not in the interest of the minority shareholders. ${ }^{157}$ However, it could be argued that the main shortcoming of the listing rules is the failure to provide a fair price after the

\footnotetext{
155 PowerPoint_Workshop, supra note 12 at slide 24.

156 Ibid.

157 CMA, 8th Annual Report (2018-2019), p. 40.
} 
decision to withdrawal. Here, an argument could be made that if delisting rules encompass insufficient protection for the minorities, shareholders tend to be reluctant. That is discussed as follows.

First, the listing rules raise the concern of share price manipulation due to concentrated ownership in the hand of major shareholders. That is because in the emerging market there is the issue of a rigorous asymmetry of information between the large shareholders, the insider, and the small shareholder, the outsider. ${ }^{158}$ The rules provide that any person could offer to purchase the shares from a shareholder who is willing to sell his shares before delisting, with no less than the minimum average price of the last 6 months of trading, counting from the disclosure date of the board's recommendation to withdraw. ${ }^{159}$ From the CMA's perspective, these rules protect the rights of minority shareholders. However, there is concern that major shareholders, acting as board members, could manipulate the share price and choose the starting date of the 6 months period. Arguably, because there is a distinguishing case in Kuwait, where a Chairman of Al-Ahli Bank of Kuwait was penalised more than 5 million USD for trading insider information and manipulating the share prices. ${ }^{160}$ This happened when the chairman — the first defendant-disclosed insider information to one of his relatives-the second defendant-concerning the quantity and the timing of the offer of the bank's treasury shares. ${ }^{161}$ The Kuwaiti court fined the first defendant an amount of 2.5 million KD and return of another 2.5 million and fined the second defendant an amount of 100,0000 KD. ${ }^{162}$ This supports the statement that, in the MENA region, the potential of insider dealing increases where the board of directors own a significant stake in the listed companies. ${ }^{163}$

Second, a 6-month price starting from a decision in the hands of the majority still did not constitute a share price that was supposed to be established through 'an independent appraisal' as recommended by the oECD. ${ }^{164}$ The old simple legal procedures in Kuwait may enabled the dominant group to easily

\footnotetext{
158 Al-Wasmi, supra note 119 at 42.

159 Kuwait, CMA, Executive Bylaws, Module 12: Listing Rules, Article 2-5-2.

16o Arabian Business, Kuwaiti Bank Chief Fined Over Alleged Insider Trading, available online at https://www.arabianbusiness.com/kuwaiti-bank-chief-fined-over-alleged-insider -trading-541224.html (accessed 16 April 2021).

161 Noura al-Mutairi, Regulating Purchase Offers for the Purpose of Acquisition and the Protection of the Minority Shareholders in Shareholing Companies in Accordance with Kuwaiti Law (Cairo: Dār al-Nahdah al-'Arabia, 2017), p. 29.

162 Ibid.

163 Amico, supra note 1 at 36.

164 OECD, The G20/OECD Principles of Corporate Governance 2015: A Critical Assessment of Their Operation and Impact (Paris: OECD Publishing, 2015), p. 26.
} 
call for an ordinary meeting and make the decision to delist from the market. Hence, the rule was not sufficient to provide a fair price for shareholders who choose to sell their shares from the delisted company. But it could be considered more of a privilege to the majority than a protection for the minority. Since the prevailing behaviour of local investors in the Middle East is to fear taking up battles with powerful controlling shareholders and board members representing dominant families and governmental bodies. ${ }^{165}$ With a high skill of bargaining, minority shareholders will have no problem to exit from the company politely with less than a fair price.

Third, choosing the average price of the shares from the disclosure date of a company's decision to withdrawal does not constitute a fair price due to market reaction. ${ }^{166}$ Since many studies show that companies experience a drop in share price between $8.5 \%$ and $12 \%$ (a high percentage) shortly after the initial announcement of withdrawal, ${ }^{167}$ minority shareholders in Kuwait may be exposed to a substantial lost even before the delisting. This supports the former point that these provisions are benefiting the major shareholders, as to buy shares at a lower price. Hence, it is plausible to suggest that the average price should be chosen from a period before announcement of the delisting.

Fourth, the listing rules do not provide any protection for minority shareholders who lose a substantial value of their shares after the delisting. Untradeable shares become worthless once the company exits from the market. ${ }^{168}$ This drop could be linked to the fact that shares convert from being priced in the Boursa to unquoted in the отс, raising the concern of exposing the shareholders to risk and banks requiring more guaranties. ${ }^{169}$ When applying the exit or voice theory ${ }^{170}$ in this situation, a minority shareholder will incur fewer costs

\footnotetext{
165 Amico, supra note 1 at 42.

166 Christian Leuz, Alexander Triantis \& Tracy Yue Wang, 'Why do Firms go Dark? Causes and Economic Consequences of Voluntary SEC Deregistrations', Journal of Accounting and Economics 45(2-3) (2008): 181-208, at 182.

167 Gary C. Sanger \& James D. Peterson, 'An Empirical Analysis of Common Stock Delistings', Journal of Financial and Quantitative Analysis 25(2) (1990): 261-273, at 265; Andras Marosi \& Nadia Massoud, 'Why do Firms go Dark?', Journal of Financial and Quantitative Analysis 42 (2007) 421-442.

168 Ernie B. Calucag, 'Is There Life after Delisting?', Biz Daily (4 March 2011), available online at http://bizdaily.com.sg/newsite/is-there-life-after-delisting/ (accessed 21 Sept. 2013), cited by Khort, supra note 153, at 4 .

169 Alaa Alsamman, 'Companies withdraw from the Stock Exchange: Who is Responsible?, April 2017, available online at https://www.alraimedia.com/Home/Details?Id =948fi767-fcf 4-4a89-b129-e86386a75o8o, accessed 16 April 2021).

170 Albert O. Hirschman, Exit, Voice, and Loyalty: Responses to Decline in Firms, Organizations, and States, (Cambridge, MA: Harvard University Press, 1970).
} 
if he exits than if he decides to stay with unquoted shares and uncertain dividends. As the law does not provide protection for loyal shareholders, they lose the opportunity to have at least a priced share with a probability of profit. Thus, the situation is more of an invitation for minority shareholders to exit rather than to stay, as there is no sufficient surety for them to keep their shares in a delisted company. Here, minority shareholders are the most negatively affected by the withdrawal decision.

The discussed shortcomings in the listing rules support the view that the prospect of voluntary withdrawal discourages investors from buying shares in the market. ${ }^{171}$ It also supports the conclusion that small shareholders tend to be reluctant when the governance system, which ordinarily encompasses legal protections, securities regulations dealing with the distribution of information, and insider trading regulations, does not provide sufficient protection for minority shareholders. ${ }^{172}$ Hence, they are discouraged from buying stocks, contributing to a concentration of ownership and shares being possessed by a few major shareholders. ${ }^{173}$ This may create a higher level of minority shareholder passivity around participating in company dealings as well as in the market as a whole.

\subsubsection{An Unfair Voting System}

Theoretically, shareholders govern a company by exercising their voting rights. ${ }^{174}$ Voting rights are considered a cornerstone for shareholders to leverage their power. Through voting, shareholders are entitled to several rights under the Kuwaiti system, most importantly, electing and appointing members to the board of directors, attending the general meetings, taking part in discussions, and voting on the matters presented in these meetings. ${ }^{175}$ In general, the voting system in Kuwait is 'one vote per one share, ${ }^{176}$ which includes all the common shares. ${ }^{177}$ At the same time, the KCL gives the right to the company's contract ${ }^{178}$ to create and distribute a class of shares referred to as 'preferred

171 Alqabas (e-editor), Boursa Kuwait is witnessing Withdrawals of Listed Companies (14 April 2014), available online at https://alqabas.com/article/38260o--بورصة-الكويت تشهد-انسحاب_شركات -من - الإد

172 Kaen, supra note 148 at 24.

173 Ibid.

174 Ibid., p. 179.

175 Ibid.; Kuwaiti Companies Law No. 1, 2016, Articles 178, 182, 188, 208 and 211.

176 Al-Saidi \& Al-Shammari, supra note 98 at 147.

177 Kuwaiti Companies Law No. 1, 2016, Article 153.

178 According to Article 10 of KCL 2016: 'The Company Contract of the two forms of Shareholding Companies shall include the Memorandum of Incorporation and Articles of Association'. 
shares', which provide more privileges. ${ }^{179}$ Although the rule of one vote per one share is often considered the ideal democratic rule supporting the governance structure, ${ }^{180}$ it has its own limitations in the Kuwaiti context. These limitations can diminish the role of active shareholders for the following reasons.

The first reason is that, arguably, 'one vote per share' may diminish minority shareholder activism because the voting is not per shareholder, but per share. ${ }^{181}$ This means that a shareholder's proportionate rights are based on the amount of capital ownership one has. ${ }^{182}$ This leads to different positions among shareholders. ${ }^{183}$ Under the one vote per share framework, power is gained by the number of shares and not by virtue of the shareholding. ${ }^{184}$ This type of rule creates a separation of influence, but only major shareholders can earn significant influence in controlling the company's performance. ${ }^{185}$ It has been shown that under this voting system, those who own less than a $5 \%$ holding are left with no representation on the board. ${ }^{186}$ That, of course, prevents the minority from participating in the management and the policymaking of the company. ${ }^{187}$

A second limitation to the voting system resulted from the new laws. After 2012, the new Kuwaiti companies' law permitted companies to issue a new class of shares known as preference shares. ${ }^{188}$ These shares have more value than ordinary shares with respect to 'voting, profits, liquidation proceeds, or any other rights' given to shareholders. ${ }^{189}$ In this scenario, the founders of a company contractually have a class of shares that enjoys the majority of voting rights. ${ }^{190}$ The founders, thus, have the right to control the company. ${ }^{191}$ Even if they issue new shares to the public, those shares will have less than $50 \%$ of the voting rights. ${ }^{192}$ Consequently, the public is only entitled to cash flow rights, but can no longer actively contribute to electing the board members

\footnotetext{
179 Kuwaiti Companies Law No. 1, 2016, Article 153.

180 Kaen, supra note 148 at 18 o.

181 Jonathan Charkham, Keeping Better Company: Corporate Governance Ten Years On (Oxford: Oxford University Press, 2005), p. 337.

182 Ibid.

183 Ibid.

184 Ibid.

185 Al-Saidi \& Al-Shammari, supra note 98 at 148.

186 Ibid., p. 133.

187 Ibid.

188 Decree Law No. 25 of 2012 regarding the Issuance of the Companies Law, Article 153.

189 Kuwaiti Companies Law No. 1, 2016, Article 153.

190 Kaen, supra note 148 at 180.

191 Ibid.

192 Ibid.
} 
or to any other decision that controls the company. ${ }^{193}$ Here, multiple classes of shares are used to separate the right to cash flow from the right to control. ${ }^{194}$ Specifically, the KCL permits a company in the formative stage to issue and grant preferred stock. ${ }^{195}$ This allows founders to give themselves or other dominant groups of the company preference shares rather than common shares. Thus, a multiple share class may be used in Kuwaiti companies as a tool to separate cash flow from the control rights in order to empower the dominant large shareholders. Kuwaiti law provides that all shareholders in the same class of shares are equal. ${ }^{196}$ However, in reality, all shareholders may be equal, but some are more equal than the others. ${ }^{197}$

A third limitation is that the Kuwaiti system has not effectively incorporated cumulative voting. ${ }^{198}$ Cumulative voting acts as a surety for minority shareholders in selecting a representative, or at least creates a greater probability of selecting one of their representatives for the board of directors. ${ }^{199}$ With cumulative voting, shareholders have the option to either focus their entire votes on a single candidate or cooperate with other fellow shareholders to elect a member to represent their views on the board. ${ }^{200}$ Here, cumulative voting can be a good method for shareholders to build alliances. That is because cumulative voting is consistent with the provision of the KCL and its executive bylaws, which allows for shareholders to 'form an alliance ... to jointly appoint one or more of their representatives in the board of directors in proportion to their shareholding. ${ }^{201}$ The latter rule has been exploited by minority shareholders in many companies in Kuwait, enabling them to join forces with other shareholders. ${ }^{202}$ Thus, cumulative voting is an essential tool for shareholder activism in Kuwait.

\footnotetext{
193 Ibid.

194 Ibid.

195 Kuwaiti Companies Law No. 1, 2016, Article 153.

196 Ibid., Article 177.

197 Charkham, supra note 181 at 337.

198 Kuwaiti Companies Law No. 1, 2016, Article 209; Kuwaiti Companies Law, Executive Bylaws of 2016, Article 118.

199 Kaen, supra note 148 at 181.

$200 \quad$ Ibid., p. 182.

201 Kuwaiti Companies Law No. 1, 2016, Article 188; Kuwait Companies Law, Executive Bylaws, 2016, Article 118.

202 Capital Markets Authority, 'Cumulative Voting and Protection of Minority Rights', by. Khaled A. al-Saeed: Board Member of the Union of Investment Companies (CMA, 2018), under the name of scientific material: available online at https://www.cma.gov.kw/en /web/cma/awarenessevents/-/cmageneric/511277. Slide 5 henceforth referred to as Power Point_Workshop2.
} 
However, the KCL provision only recommends that companies stipulate cumulative voting in their contract as the mechanism for electing members of the board. ${ }^{203}$ This provision is critical for two reasons. First, it gives the founder the authority to adopt this tool in the company's contact, raising the concern that he can prioritise his interest in the company when making the decision. The second is that the recommendation using cumulative voting is not conducive to initiatives that would force companies to adopt this measure. At present, the situation in Kuwait is the same as other countries in the region that have failed to mandate the use the cumulative voting but rather only recommend it as a governance best practice. ${ }^{204}$ Thus, the same concern can be raised in the Kuwaiti context that failing to enforce the cumulative voting mechanism negatively impacts minority rights. ${ }^{205}$

The fourth and final limitation to a fair voting system is the negative impact of domination of the major groups. For instance, cumulative voting was mandatory under the previous Companies Law No. 25 of 2012, before it was revised in 2013 in accordance with Companies Law No. 97 of $2013 .{ }^{206}$ Many claim that forcing companies to adopt the cumulative voting system was considered a failure. ${ }^{207}$ In the most recent official public poll about cumulative voting conducted by the CMA in $2018,51.8 \%$ of listed companies did not agree with imposing cumulative voting. This is mainly because this voting method would restrain the right of major shareholders, particularly the controlling family groups or 'semi-family companies', ${ }^{208}$ which found this method of voting to be

203 Kuwaiti Companies Law No. 1, 2016, Article 209; Kuwaiti Companies Law, Executive Bylaws of 2016, Article 118.

204 OECD, Guide on Related Party Transactions in the MENA Region (2014), available online at http://www.oecd.org/corporate/GuideonRelatedPartyTransactionsMENA2014.pdf, p. 13 (accessed 17 April 2021).

205 Ibid.

206 According to Article 240 of Decree Law No. 25 of 2012, which refers to the Issuance of the Companies Law'. Voting on candidates for membership of the board of directors in public joint-stock companies is subject to a cumulative voting system, which entitles each shareholder to a number of votes equal to the number of shares owned by him. He is entitled to use his votes for one candidate or to distribute such votes among a number of candidates, without any of such votes being used more than once'.

207 Capital Markets Authority-Awareness Office, 'The results of opinion polls on the cumulative votings' (CMA, 2018), available under the name of scientific material at: https://www .cma.gov.kw/en/web/cma/awarenessevents/-/cmageneric/511277 (accessed 10 April 2021), slide 9 henceforth referred to PowerPoint_Workshop3.

208 In this context, we can refer to the 'semi-family company' as a public shareholding company controlled by a family. Usually, the family believes that it owns the company, even if the company is publicly listed, with other shareholders having a say in its running. 
an obstacle to running the company. ${ }^{209}$ The poll also noted that $51.8 \%$ of these companies believe that there are many obstacles facing the implementation of this method. ${ }^{210}$ First, the majority shareholders, known as 'the dominant groups' will refuse to use cumulative voting since it negatively affects their control in the company. ${ }^{211}$ Secondly, the lack of minority awareness of this method will lead to electing inappropriate candidates for the board. ${ }^{212}$ Thirdly, cumulative voting creates a state of heterogeneity among the board members, which affects the company's investment decisions. ${ }^{213}$ Fourth and finally, the KCL does not compel companies to adopt cumulative voting, ${ }^{214}$ and most companies find no reason to adopt this method. Accordingly, $51.8 \%$ of listed companies in the survey preferred to use the method of common voting rather than cumulative voting. ${ }^{215}$ In fact, from the perspective of some companies in Kuwait, cumulative voting is an unfair process because it deprives the shareholders of electing all board members. ${ }^{216}$ That sentiment reflects a globally held common belief of those who oppose cumulative voting, based on the fact that the board of directors should represent all shareholders in the company. ${ }^{217}$ Despite the sentiment, $64.3 \%$ of listed companies believe that cumulative voting is an effective tool for protecting minority rights. ${ }^{218}$ Still, $94.6 \%$ of listed companies believe that the minority shareholders need more awareness and education about this method. ${ }^{219}$ Hence, cumulative voting is not suitable for the context and the status of listed companies in Kuwait, due to major shareholders' concentration of ownership.

\subsubsection{Weak Monitoring Instruments}

Conceptually, shareholders in Kuwait are entitled to monitor the management of the company. ${ }^{220}$ The shareholder's right to monitor includes the right to appoint the company's auditor, determine his compensation, and

\footnotetext{
209 PowerPoint_Workshop3, supra note 207 at slides 5 and 6.

210 Ibid., slides 9 and 10.

211 Ibid., slide 9.

212 Ibid.

213 Ibid.

214 Ibid.

215 Ibid., slides 13 and 14.

216 PowerPoint_Workshop2, supra note 202 at slide 6.

217 Kaen, supra note 148 at 182.

218 PowerPoint_Workshop3, supra note 207 at slide 16.

219 Ibid., slide 19.

220 Tamah Alshammari \& Abdullah Alhayan, Mediator in Explaining the Kuwaiti Companies Law (Kuwait: 2014), p. 442.
} 
ask questions about the financial report in the annual general meeting. ${ }^{221} \mathrm{~A}$ shareholder also has the right to inspect the company's books and records. ${ }^{22}$ However, there is an argument that monitoring rights are not well supported in the law and KCCG in Kuwait. As we shall see below, the weak monitoring rights of shareholders plays an important role in diminishing a shareholder's role in the company, as explained below.

First, the rules concerning a shareholder's right to appoint the auditor are rather flexible. The KLC provision actually permits the shareholders to authorise the board of directors to appoint the auditor and determine his remuneration..$^{223}$ There is also a longstanding practice that the general assembly will appoint the auditor based on the recommendation of the board of directors. ${ }^{224}$ These two alternative appointments raise concerns about existing nepotism between the auditor and the board of directors. ${ }^{225}$ There is a fear that, if appointed in this fashion, the auditor would be loyal to the board rather than to the company and the shareholders. ${ }^{26}$ This suspends the point of independence for an auditor, whose role is to monitor the board of directors. In solving this issue, some suggest that, to ensure auditor independence, there should be an independent committee chosen by the shareholders, that is responsible for appointing the auditor and determining his compensation. ${ }^{227}$ The committee then provides a recommendation to the general assembly who votes to appoint. ${ }^{228}$

Surprisingly, the KCCG 2015 takes a paradoxical approach that does not support the concept of an independent auditor. First, it requires the board of directors to form an Audit Committee; the board has the authority to determine the term of committee membership and define the mechanisms of its operations. ${ }^{229}$ Some of the committee's responsibilities are to 'provide the board of directors with its recommendations concerning the appointment, re-appointment, or replacement of the External Auditors, and specify their remunerations [and] [f] ollow up works of External Auditor and ensure no services other than services

\footnotetext{
221 Kuwaiti Companies Law No. 1, 2016, Article 211; CMA, Executive Bylaws, Module 15: Corporate Governance (2015), Article 9-9.

222 Kuwaiti Companies Law No. 1, 2016, Article 289.

223 Alshammari \& Alhayan, supra note 220 at 442.

224 Ibid., p. 443.

225 Ibid.

226 Ibid.

227 Ibid.

228 Ibid.

229 Article 5-6 of Module 15: Corporate Governance (2015) states: 'The Board of Directors shall form an audit committee, in which the number of members shall not be less than three, provided that at least one of the members shall be independent. The Board Chairman or Executive Members of a Board of Directors shall not be members in such committee'
} 
related to audit functions are provided to the company.'. ${ }^{230}$ These responsibilities would seemingly permit the Audit Committee, that consists of member of the board of director, to monitor the auditor; it also negatively affects an auditor's independence as the committee specifies the auditor's compensations. Second, the rules explicitly require that the shareholders, through the general assembly, appoint the auditor based on the proposals of the board of directors. ${ }^{231}$ That process, of course, involves intervention of the board and detracts from the sacrosanct right of shareholders in appointing the auditor. The KCCG 2015 directly contradicts the KCL rules, which emphasise the important role of the independent auditor in the company, ${ }^{232}$ as well as the role of the auditor in monitoring the board of directors. ${ }^{233}$ Also, the KCCG 2015 does not account for the idea that ,under the KCL, the auditor owns duties toward the company and its shareholders, not the board of directors. ${ }^{234}$ This raises the larger concern that the code is violating a higher regulation, the KCL, which granted the CMA the authority to issue the Code. ${ }^{235}$ The rules concerning the external auditing in the KCCG are void since they contradict the KCL. This supports the finding that the inconsistency of the provisions of the KCCG with those of company law in other MENA countries leads to confusion among listed companies concerning the application of $\mathrm{CG}$ standards. ${ }^{236}$ The monitoring role of the shareholders in the company diminishes as the board of directors gain significant power over the auditor. Contradiction in the law and the legal frailty that accompanies it empowers major shareholders to gain dominion and control

230 Kuwait, CMA, Executive Bylaws, Module 15: Corporate Governance (2015), Article 5-7.

231 Ibid., Article 5-8.

232 According to Article 229 of the KCL, "The auditor shall at any time have the right of access to the company's books, registers and documents and may request any details he deems necessary. He shall also have the right to verify the company's assets and liabilities. If the auditor is unable to exercise such rights, he shall report this in writing to the board of directors, which shall submit this to the ordinary general meeting and shall serve the Ministry and the Authority with a copy thereof'. Also, according to Article 230, the auditor is responsible for providing an annual financial statement.

233 According to Article 23o, the auditor shall specify in the financial statement whether the data contained in the board of directors' report are consistent with the facts established in the company's books and documents in accordance with the generally accepted auditing principle. Also, the auditor must specify if there have been violations of the provisions of the law or the company contract during the financial year and whether these violations still exist, to the extent such information is made available to the auditor.

234 Kuwaiti Companies Law No. 1, 2016, Article 232.

235 Kuwait Chamber of Commerce and Industry Memorandum on the decision of the Capital Markets Authority to issue rules under its corporate governance, available online at https://www.kuwaitchamber.org.kw/echamber/website/index.jsp?pageID=ws_cmsmenu .jsp\&fromPublic =yes\&language $=$ ar\&rootMenu $=549 \&$ menuID=549\#:searchListReport@5 (accessed 17 April 2021).

236 Amico, supra note 1 at 5 . 
over a company's decision making. Thus, shareholders in Kuwait have no genuine role in scrutinising the financial statements of the company. Not only does this impact the integrity of the financial reports, it also marginalises the role of shareholders in monitoring their companies.

Second, the KLC does not support the shareholder's right to inspect the company's books and records. Under the law, an auditor plays an important role as intermediary for shareholders in inspecting the company's books and records; they are allowed to inspect these records at any time. ${ }^{237}$ If the role of an objective auditor is inhibited, can the shareholders themselves inspect their shareholding company's books at any time? This is an important question because active shareholders have to be cognisant of the operations and activities of the company; if not, then a shareholder will not be able to recognize and take action against board misconduct. ${ }^{238}$ Here, a shareholder's right to access the data and records of the company is crucial within the context of shareholder activism.

Third, shareholders right to individually inspect the company's records is not clearly supported by the KCL. In general, shareholders in Kuwait have the right 'to access to data and information of the company activity and operational and investment strategy regularly and easily'.239 Under the Kuwaiti system, shareholders have the right to access a few company documents such as records of shareholders and bond owners, records of disclosures regarding members of a board of directors and the executive management, and records that include the directors' names or those delegated to sign on behalf of the company. ${ }^{240}$ Unlike shareholders in other forms of companies, the laws do not explicitly grant shareholders of a shareholding company the right to inspect the company's records and books. ${ }^{241}$ While the Kuwaiti law is silent about this issue, some have argued that an individual shareholder in big companies, such as closed shareholding companies and public shareholding companies, cannot have the freedom to access and inspect the records at any time because this would interrupt the company's work. ${ }^{242}$ Then, if shareholders sense that the board has conducted a breach, an individual shareholder can request the supervisory entity to conduct an inspection or appoint a new auditor. ${ }^{243}$ However, weaknesses in the law and the empowerment of major

\footnotetext{
237 Kuwaiti Companies Law No. 1, 2016, Article 229.

238 Keay, supra note 67 at 286.

239 Kuwait, CMA, Executive Bylaws, Module 15: Corporate Governance (2015), Article 9-5.

240 Ibid., Articles 9-7 and 8-6; Kuwaiti Companies Law, Executive Bylaws of 2016, Article 113.

241 Kuwaiti Companies Law No. 1, 2016, Articles 47, 59, 69, and 107.

242 Alshammari \& Alhayan, supra note 220 at 428 and 429.

243 Ibid.
} 
shareholders leave minority shareholders in a fragile state when it comes to their monitoring rights. Thus, shareholders could have the right to individually inspect the company's records for several reasons.

Firstly, minority shareholders lack the right to request an appointment of a new auditor to conduct an inspection, since that right is only conferred to shareholders owning at least $5 \%$ of the company's capital. ${ }^{244}$ Secondly, even if a shareholder could request an inspection, the procedures for such a request would come at a cost. When filing the request, a shareholder must pay 200 $\mathrm{KD}$ - more than 6oo USD - as a non-refundable fee to the Ministry; the shareholder also must agree to personally compensate the new auditor, ${ }^{245}$ a rather high cost for an individual shareholder. If the inspection does not find any irregularity, the shareholder must also pay to publish the results of the inspection in two daily newspapers and the company's website. ${ }^{246}$ Despite the heavy onus on shareholders, there are no provisions if the inspection confirms the shareholder's claim; also, the rules do not set a time limit for the Ministry to respond to these requests. Because of the procedures' heavy financial and time constraints, shareholders will likely fail to properly monitor their companies in this way. ${ }^{247}$ Shareholders will prefer to stay passive rather than bear the costs of monitoring their companies. However, individual inspection would encourage participation since it would be less expensive and time-consuming than government procedures for auditors. Thirdly, the KCL expressly states that inspecting a company's book is beyond the scope of intervention. ${ }^{248}$ Accordingly, in other forms of companies (general partnership companies, limited partnership companies, partnerships limited by shares), the law confers the right to inspection to non-managing partners and limited partners, either by themselves or through a representative. ${ }^{249}$ If shareholders are considered as non-managing partners or limited partners of a shareholding company, they may earn the right to closely and regularly inspect the company's records. Fourth, shareholders are considered an 'interested party' and the KCCG 2015 recognises their interest in raising the value of their investments. ${ }^{250}$ Thus, shareholders are entitled to the right to inspect the books to protect their interest in the company.

\footnotetext{
244 Kuwaiti Companies Law No. 1, 2016, Article 298; Kuwaiti Companies Law, Executive Bylaws of 2016, Article 138.

245 Kuwait Companies Law, Executive Bylaws of 2016, Article 138.

246 Ibid.

247 Keay, supra note 67 at 286.

248 Kuwait Companies Law No. 1, 2016, Article 59.

249 Ibid., Articles 47, 59, 69, and 107.

250 Kuwait, CMA, Executive Bylaws, Module 15: Corporate Governance (2015), Article 9-1.
} 


\subsubsection{Cultural and Social Factors: The Culture of Apathy}

Although all these shortcomings provide a sufficient explanation for the passivity of shareholders in Kuwait, shareholders still have a place to amplify their voices through participation. The reluctance of shareholders to participate is captured at the annual general meeting (AGM) and filing lawsuits against the board of directors. First, shareholders have increasingly become less engaged during AGMs. ${ }^{251}$ Under the Kuwaiti legal system, shareholders have an active and participatory role in the AGM. While attending a meeting is a shareholder's inherent right, a shareholder also has the right to vote and take part in discussions during the meeting. ${ }^{252}$ Furthermore, not only do shareholders have the right to discuss matters that are included in the agenda, they can also add urgent matters that the board did not include in the agenda. ${ }^{253}$ Most importantly, the shareholders have the right to ask questions and discuss their reports, not only with the board members but also with the auditor. ${ }^{254}$ Shareholders have a high level of freedom to ask questions, including questions related to any company secrets that directors discover during the course of their directorship. ${ }^{255}$ Despite the vast rights available to them during an AGM, shareholders in Kuwait tend to remain dormant. Although the CG code compels companies to allow shareholders to effectively participate in AG Ms, ${ }^{256}$ shareholders do not properly scrutinise boards of directors. ${ }^{257}$ They do not even ask about the information that the board relied on when making the company's investment decisions. ${ }^{258}$ Second, and most importantly, voluntary delisting indicates the lack of litigation culture among shareholders in Kuwait, because the voluntary withdrawal decision may constitute a ground for filing a liability lawsuit against the board. If the shareholders can show that the decision was a result of fraud or misuse of power, or of violation of the law and the Company Contract or a management error, then a minority shareholder

251 Al-Melhem, supra note 99 at 430.

252 Kuwait Companies Law No. 1, 2016, Articles 178 and 208; CMA, Executive Bylaws, Module 15: Corporate Governance (2015), Article 9-8.

253 Kuwait Companies Law 2016, ibid, Articles 211 and 213; Kuwait Companies Law, Executive Bylaws of 2016, Article 118.

254 Kuwait, CMA, Executive Bylaws, Module 15: Corporate Governance (2015), Article 9-9 (5); KCL 2016 Article $23^{2}$.

255 This is a conclusion contrary to Article 196 of the KCL 2016, which prohibits directors from disclosing any secrets of the company they may come to know of during their directorship to shareholders or any third party other than at the annual general meeting.

256 Kuwait, CMA, Executive Bylaws, Module 15: Corporate Governance (2015), Article 9-8.

257 Al-Melhem, supra note 94 at 430.

258 Ibid. 
is entitled to file a derivative suit. ${ }^{259}$ However, the CMA Report did not indicate a significant number of shareholders challenging the withdrawal decision through litigation. ${ }^{260}$ On the contrary, it suggested that shareholder apathy encouraged the majority group to make the withdrawal decision alone, without any pushback from minority shareholders. ${ }^{261}$ In Kuwait, shareholder apathy is a result of shareholders having a minor role in holding the board accountable. Private enforcement is 'virtually non-existent' in the region, including Kuwait, due to a lack in litigation culture. ${ }^{262}$ Consequently, such passivity has encouraged directors to participate in conflict of interest transactions since their actions are never questioned. ${ }^{263}$ Thus, shareholders are reluctant to practise their role in the company and demand better governance. This subsection indicates that the culture of shareholder apathy is the product of different circumstances and cultures present in Kuwait, such as the long litigation proceedings, free-riding problem as a result of non-existent shareholder associations, shareholders' speculative approach, and social interaction of business in Kuwait, which will be discussed below.

\subsubsection{Long Litigation Proceedings}

First, long litigation proceedings could discourage small shareholders from filing a lawsuit. Although the judicial system in Kuwait is known to be relatively independent, shareholders in Kuwait do not effectively bring lawsuits due to the absence of a litigation culture; not only is there no precedent to support the shareholder, but there is also a lack of shareholder associations. ${ }^{264}$ In general, the fact that the recoveries of the derivative suit go to the company and only proportionally to the single shareholder is one of the obstacles to bringing a derivative action. ${ }^{265}$ However, the lack of shareholder litigation could be attributed to the length of litigation proceedings, as Kuwaiti regulations do not set a time limit for the court to adjudicate the cases before them, and commercial cases remain subject to long litigation. ${ }^{266}$ Such delays in proceedings led to 7000 accumulated commercial appeals before the Supreme

\footnotetext{
259 Kuwait Companies Law No. 1, 2016, Articles 201 and 203.

26o Video_Workshop, supra note 11 at 23:08-23:12.

261 Ibid.

262 Amico, supra note 1 at 29 and 3 .

263 Ibid.

264 Amico, supra note 1 at 32; Boubaker \& Nguyen, supra note 68 at 541.

265 Amico, ibid., p. 41.

266 Hussein al-Abdullah, Establishing Economic Courts is a Necessity ... and the Legislator Must set a Time for Litigation, Al-Jarida (Kuwait City, November 2019), available online at https://www.aljarida.com/articles/1574695254325658300/ (accessed 17 April 2021).
} 
Court in 2019 and 3281 pending commercial cases in 2020 with only $9.9 \%$ cases adjudicated. ${ }^{267}$ Another example of the long litigation proceedings in Kuwait is the high number of adjourned cases, namely 27431 commercial cases in different courts during 2019 and 27595 cases during 2020.268 This may support the finding that litigation proceedings in MENA countries usually takes about 651 days, which is longer than the time limit set by international standards. ${ }^{269}$ Despite that Kuwait has recently adopted the establishment of the Capital Market Authority Court to look at disputes related to CMA law and bylaws, ${ }^{270}$ the law does not require judges to have either expertise or knowledge of economic matters. ${ }^{271}$ Therefore, Kuwait does not have specialised economic courts for financial markets, for investment, banking and insurance issues, which has negatively affected the efficiency of the judicial system in resolving commercial cases. ${ }^{272}$ The lack of efficiency has been the main barrier for shareholders who want to bring legal action. ${ }^{273}$ It is plausible to suggest that Kuwait, like Qatar and UAE, should take a further step and consider establishing separate commercial courts. ${ }^{274}$ Also, it may be plausible to suggest that the Kuwait Boursa could follow Brazil, as an emerging market, in providing a listed company with access to a Market Arbitration Panel to resolve conflicts that arise between shareholders and their investee company, which might be considered a better alternative than a court trial. ${ }^{275}$

\subsubsection{Absence of Shareholder Institutions and Free-Riding}

Second, the absence of shareholder institutions in Kuwait supports the existence of free-riding problem of minority shareholders. In light of the domination of large shareholders in Kuwait, only these shareholders have the ability to monitor the management for their own interest; small shareholders have

\footnotetext{
الفصل 267 Ibid., https://www.moj.gov.kw/AR/Documents/OpenData/20\% 202020\% \% التمبيز.pdf(accessed 17 October 2021).

268 Available online at https://www.moj.gov.kw/AR/Documents/OpenData/Case_PostPone 2019.pdf: https://www.moj.gov.kw/AR/Documents/OpenData/المؤجل 20\% 20\% 2O2O2O\% \% المختلفة/20\%.pdf (accessed 17 October 2021).

269 Amico, supra note 1 at 32.

270 Kuwait, CMA, The establishment of the Capital Markets Authority and Regulating Securities Activities and its Amendments Law No. 7 (2010), Article 108.

271 Ibid.

272 Al-Abdullah, supra note 266.

273 Boubaker \& Nguyen, supra note 68 at 541.

274 Ibid.

275 Robert A.G. Monks \& Nell Minow, Corporate Governance, 5 th edn. (Oxford: Wiley, 2011), p. 419 .
} 
neither the ability nor intention to monitor due to the cost of the monitoring process. ${ }^{276}$ They tend to benefit as 'free-rider' from the efforts of large shareholders in monitoring. ${ }^{277}$ Hence, they let large shareholders take the lead and exert their power over the company. ${ }^{278}$ The cost of monitoring and the problem of free-riding discourages any small shareholder who wishes to engage in monitoring, ${ }^{279}$ which contributes to the culture of apathy in Kuwait. Since there are no shareholder associations functioning in Kuwait, or in the entire MENA region, small shareholders do not have a way to mitigate the cost of shareholder activism, thus resulting in the tendency of small shareholders to lean on larger shareholders. ${ }^{280}$ Thus, absence of shareholder institutions is one of the obstacles to effective shareholder engagement.

\subsubsection{Retail Investors as Speculators}

Third, in Kuwait, the characteristics of the retail investor ${ }^{281}$ could explain such apathy. Although the Kuwait Boursa as an emerging market has highly concentrated ownership through institutional shareholders, the government, and dominant families, minority shareholders (retail investors) also control a significant stake in the Boursa. The total concentration of retail investors in the Kuwaiti Market ranged from 54\% to $57 \%$ during the period from 2017 to 2020 as shown in Table 3. A recent study estimated that the value of retail trades in the Kuwaiti Boursa was $40 \%$ in $2016 .{ }^{282}$ Therefore, retail investors are considered one of the dominant shareholders in the MENA countries, including Kuwait. ${ }^{283}$ Such retail investors have been described as 'speculative investors'. ${ }^{284}$ However, because there is a shortage of data about the behaviour of investors in the region, ${ }^{285}$ there is no clear definition of what constitutes a speculator in the Kuwaiti market. Nevertheless, we can form a general idea about what a speculative shareholder in Kuwait is by looking at the general concept

276 Sanford J. Grossman \& Oliver D. Hart, 'Takeover Bids, the Free-Rider Problem, and the Theory of the Corporation', The Bell Journal of Economics 11(1) (1980): 42-64.

277 Keay, supra note 67 at 286.

278 Al-Saidi \& Al-Shammari, supra note 98 at 154 .

279 Keay, supra note 67 at 286.

28 o Boubaker \& Nguyen, supra note 68 at 547.

281 According to the Cambridge English Dictionary, a retail investor is 'a member of the public who makes investments, not a large organization or business that makes investments'. Thus, it is a non-professional individual, available online at https://dictionary.cambridge .org/dictionary/english/retail-investor (accessed 17 April 2021).

282 Amico, supra note 1 at 45 and 46.

283 Boubaker \& Nguyen, supra note 68 at 545 .

284 Amico, supra note 1 at 11.

285 Boubaker \& Nguyen, supra note 70 at 546. 
of speculator, namely someone who hopes to make a short-run profit in the market. ${ }^{286}$

There are two reasons why small shareholders in Kuwait are reluctant to exercise their legal rights. First, small shareholders do not believe they have the ability to challenge major shareholders. ${ }^{287}$ Second, the majority of small shareholders are speculative investors with short-term objectives, who do not care what happens with the future of the company as long as they can make a quick profit. ${ }^{288}$ It has been argued that there are two categories of shareholders: permanent and temporary. ${ }^{289}$ The latter are speculators who aim to sell their shares once they increase in value; they are usually absent from general meetings. ${ }^{290}$

One of the reasons for their absence is their lack of financial and managerial experience. ${ }^{291}$ Such speculators generally lack the expertise to understand the financial reports issued by the company directors. ${ }^{292}$ As a result, their votes are a weak influence on the resolutions approved in the general meetings. ${ }^{293}$ Therefore, it can be argued that retail investors acting as speculators are more likely to be passive in Kuwait. The identity of the shareholders contributes to the lack of shareholder activism in Kuwait.

\subsubsection{Kuwait is a Small Country where Everyone knows Everyone}

Finally, it is important to look at the social interaction in businesses as one reason behind small shareholders' apathy. Kuwait has a relatively small population of 4.4 million people: 1.3 million are Kuwaitis and 3.09 million are

286 Jonathan Law, A Dictionary of Finance and Banking (Oxford:Oxford University Press, 2014), p. 374.

287 Salem Abdul Ghafoor, "The Voice of the Small Shareholders Is Muffled ... Muffled in the General Assemblies', Al-Qabas Newspaper (Kuwait City, 14 May 2018), available online at https://alqabas.com/article/536041-صوت-صغار-المسا همين-مكتوم-مكتوم-في_الع (K) (accessed 17 April 2021).

288 Ibid.

289 Ahmad R.K. al-Mutairi, Shareholders' under the Company Law of the State of Kuwait: An Evaluation of Existing Laws and Proposals for Reform, Doctoral Dissertation, Faculty of Law and Financial Studies, University of Glasgow, Glasgow, 2002, p. 241.

290 Ibid.

291 T.A. Lee \& D.P. Tweedie, Shareholder Use and Understanding of Financial Information (London: Garland Publishing, 199o), p. 27; Mahmoud al-Sharkawi, Commercial Companies in Egyptian Law, (Egypt: Dār al-Nandah, 1986), p. 231.

292 Abou Zied Radwan, Shareholding Companies in Public Sector (Egypt: Dār al-Fikr al-Arabī, 1983), p. 271; Susan A. Bartlett \& Roy A. Chandler, 'The Corporate Report and the Private Shareholder: Lee and Tweedie Twenty Years On', The British Accounting Review 29 (1997): 245-261, at 248.

293 Al-Mutairi, supra note 288 at 246. 
expatriates. The latter accounts for $70 \%$ of the population. ${ }^{294}$ Since Kuwait is a small country, where close and strong relationships exist between families and people, it is difficult to achieve strong accountability. ${ }^{295} \mathrm{In}$ fact, close relationships and nepotism have negatively affected the appointment of nonexecutive directors. ${ }^{296}$ This raises the concern that social relations impact the integrity of board of directors' meetings, making them a mere formality. ${ }^{297}$ In Kuwait, the board meeting is becoming a place for friendly chats and drinking tea and coffee, rather than a place for running company business. ${ }^{298}$ Hence, small shareholders do not vote with their feet or launch proxy fights at AGM $\mathrm{s}^{299}$ due to the powerful influence of social interactions on Kuwaiti business. Thus, social relations between shareholders are considered one of the obstacles to the effective practice of shareholder rights.

\section{4 Conclusion}

Despite the recent changes in the CG system, including the CMA's endeavour to face challenges by recalibrating the application of corporate governance from a hard approach to a mixed approach based on the 'comply or explain' principle. Still, there are challenges that hinder the good practice of corporate governance that need to be resolved. This article has highlighted the main limitations of corporate governance as reflected by the event of voluntary delisting of listed shareholding companies from the Boursa.

It also has provided a critical discussion on the limitations of corporate governance in Kuwait by examining the results of the official cMA Report on companies voluntarily delisting from the Boursa between 2010 and 2016 and by drawing on a sample of all companies that delisted from the Boursa between 2016 and 2020. Examination of voluntary delisted companies focused on four limitations hindering the effectiveness of the CG system.

First, the increasing number of companies delisting from the Boursa, despite the adoption of the more flexible approach of the new KCCG 2015, is related to the existence of a non-compliance culture among companies in Kuwait. This research divides the non-compliance culture into two aspects: the lack

294 Estimating the population numbers in the State of Kuwait according to age groups, nationalities, and genders, 1-1-202O, available online at https://www.csb.gov.kw/Pages /Statistics_en?ID=67\&ParentCatID=1 (accessed 17 April 2021).

295 Al-Saidi \& Al-Shammari, supra note 98 at 151.

296 Ibid., p. 146.

297 Alshammari \& Alhayan, supra note 220 at 397.

298 Ibid.

299 Boubaker \& Nguyen, supra note 68 at 541. 
of discipline and education, and alienation from the CG scope. Analysis of a sample of 29 companies that delisted from the Boursa between 2016 and 2020 supports the existence of non-companies in Kuwaiti shareholding companies. For the first aspect, the sample indicates that $38 \%$ of voluntarily delisted companies did not submit a CG report and were sanctioned by the CMA for not compliance with the legal requirements including the CG code. Also, 34.6\% of voluntary delisted companies did not attend the Awareness Programme. Regarding the second aspect, $96 \%$ of the voluntary delisted companies were not within the CG scope, and $73 \%$ of these companies were listed on the отс. Thus, a non-compliance culture exists among a substantial number of delisted companies.

Second, continuous voluntary delisting of companies from the Boursa, leading to a reduction in the number of companies subject to the CG code, indicates deficiencies in the legal framework of corporate governance in Kuwait. It reveals that the current approach of the KCCG 2015 does not solve the problems apparent in the former KCCG 2013. For the most part, the current approach does not differentiate between large and small companies. There is a problem of implementation because there are no criteria for providing adequate explanations for non-compliance. Finally, the Code has failed to be flexible enough to attract companies with a non-compliance culture, which prevails among listed companies in Kuwait, as illustrated by CMA Report (2010-2016) and the analysis of the sample examined. In addition, the KCL does not constitute a sufficient source of CG rules. This deficiency means that such registered companies benefit from being on the отс because they come under the light supervision of the Ministry of Commerce and Industry in implementing the law. Also, these companies are not required to follow many CG requirements relating to the independence, qualifications, experience, and technical skills of directors, to the appointment of CMA-licensed auditors, to the formation of a risk management committee, and to the adherence of provisions concerning shareholders' rights in the Code, including the right to all data set out in the disclosure record of the members of the board and the executive management. Another shortcoming in the KCL is the fragility of provisions concerning the responsibility of the board of directors, especially those related to the duty of loyalty.

Third, concentrated ownership in the hands of a few major shareholders creates problems for listed companies and shareholders. The majority shareholders, the dominant groups, hold power to make substantial decisions in the company, including withdrawing from the market because the provisions regarding withdrawal were easy and allow them to avoid market oversight. Furthermore, the concentration of ownership in the hands of large 
shareholders such as the government, dominant families, and institutional investors, raises the issue of an agency problem between these groups and minority shareholders. Groups of major shareholders have different roles to play in corporate governance, most of which negatively affect the good practice of corporate governance. For example, there is a negative relationship between governmental shareholdings and a firm's performance, implying a poor performance when the government acquires shares. Also, the concentration of ownership raises the concern of the existence of owner-managed companies, which is applicable to the Kuwaiti situation, because, in practice, whoever owns the majority of shares becomes the chairman of the board of directors. Thus, the ineffective ownership structure in Kuwait raises the issue of the diminishing role of minority shareholders due to the domination of large shareholders over the company.

Fourth, the problem of passive shareholders, another challenge of corporate governance in Kuwait, occurs for different reasons, first among them being legal factors: the insufficient protection for minority shareholders in delisted companies, the unfair 'one vote per one share' voting system, weak monitoring instruments, and, finally, cultural and social factors in Kuwait. The culture of apathy among shareholder in Kuwait is manifested in two situations: the lack of a litigation culture and ineffective participation during the AGM. The latter could be attributed to the length of litigation proceedings, the absence of shareholder institutions, 'free riding' of minority shareholders, the speculative nature of retail investors and their short-term investment agenda, and, finally, the powerful influence of social interactions on Kuwaiti business. The existence of nepotism has a negative impact on the effective practice of shareholders' rights.

Figure 1 presented these limitations as a cycle. First, it highlights the existence of a non-compliance culture in companies that are voluntarily delisted from the Boursa. The cycle then reflects the second limitation, namely deficiencies in the CG legal framework, which includes the failure of the Code's approach to recognise the culture of non-compliance that drives companies to list on the OTC rather than face CG obligations. Moreover, fragility of the KCL allows companies to operate on the отc, a restriction-free area, which is attractive to companies with a non-compliance culture and where their boards are dominated by major shareholders. The cycle shows that the inadequacy of the CG legal framework leads to the third limitation, namely concentrated ownership in the hands of major shareholders. In turn, the concentration in ownership diminishes the role of shareholders in company decision-making. The cycle then shows that this concentration leads to the fourth limitation, which is the passivity of shareholders of listed companies in Kuwait. The apathy of 
shareholders is one of the key characteristics of countries in the MENA region, including Kuwait. The prevalent culture of shareholder apathy rounds off the cycle, demonstrating that the passivity of shareholders and their ineffective monitoring role support the existence of the non-compliance culture. Thus, these limitations reflect and interconnect with each other.

In summary, this article recommends that Kuwait should take further steps toward legal efficiency and the harmonisation of its code and regulations between MENA country members. This could be met through the following reforms.

(1) The CMA should take further steps toward its goals to raise the awareness of business parties and shareholders by increasing its communication.

(2) The CMA should make alterations to the CG code, most importantly by adopting a 'gradual regulatory tightening', similarly to Saudi Arabia and Egypt, in order to raise awareness in companies, business parties and shareholders. The current approach of KCCG 2015 should become entirely voluntary, so that companies with a non-compliance culture become accustomed to following CG requirements. Thereafter the Code should be revised to become more mandatory over time. The CMA may want to examine and follow other countries in the MENA region that issue a separate CG Code that takes into account differences in the types and sizes of companies.

(3) The Kuwaiti Parliament should amend the current rules of the Kuwait Companies Law 2016, concerning shareholders' rights in monitoring the board and management, to support the right to individually inspect a company's records and to assign a company's auditor and external auditor. The KCL should be revised to have a balanced approach regarding the allocation of power in order to mitigate the agency problem between minority and large dominant shareholders. This could be met by adopting the two-tier system in creating the supervisory board in the listed shareholding companies, consisting of representatives of shareholders and employees.

(4) The CMA should play a more powerful role in supporting the economic growth by interfering in issuing appropriate economic regulations to remedy flaws in the market and activate market mechanisms to prevent the high concentration in shareholder ownership and the domination of large shareholders.

(5) Current studies in this area have provided regulators with no indication of how effective the law is regarding the economic and commercial environment and the Kuwaiti market. In our context, the preference of 
companies to be excluded from any legal restraints should be considered when evaluating the law as part of an economic analysis of the regulations in place. Thus, it is important to consider the role of the CMA in reviewing the laws and code, such as its departments of legal studies, development and legal studies, and capital markets development.

(6) The cMA should require companies within the scope of its supervision to create an online platform where shareholders can have access to all the necessary information and dates of important meetings.

(7) The CMA should create in the Kuwait Boursa a Market Arbitration Panel available for shareholders in listed companies. Finally, the CMA should support shareholders in listed companies to form a shareholder institution to spread the cost of shareholder activism and encourage shareholder engagement. 